\title{
THE EFFECT OF MINIMUM WAGES ON EMPLOYMENT IN INDONESIA
}

\author{
Leo Sukatrilaksana*)
}

\begin{abstract}
Minimum wages have been a major consideration in Indonesia in recent years, as the government has strongly pursued a minimum wage policy. The levels of regional minimum wages have been increased significantly since 1989, and there is a concern that these increases may have slowed employment growth. Therefore, the purpose of this study is to examine the employment effects of minimum wages, using data for 26 provinces, covering the period from 1988 to 1999. The study focuses on different groups of workers within the urban formal sector. The results of graphical and statistical analysis indicate some support for the conventional theory of the negative employment effects of minimum wages.
\end{abstract}

*) Analis Keuangan Yunior - Biro Perencanaan dan Pengendalian Keuangan Intern 


\section{INTRODUCTION}

I ndonesia has a large labour force, a high unemployment rate and a rapidly expanding labour market. The Indonesian labour market comprises a large proportion of workers who are sensitive to variations in parameters of a minimum wage regime. These groups include females, youth workers and less educated workers. As an illustration, females and youth accounted for 38.4 and 21.3 percent of all labour force participants, respectively, in 1999. Less educated workers accounted for $76.3 \%$ of all workers in that year. With these unique economic circumstances, the importance of minimum wages has been a major consideration in the recent years, although minimum wages have been a characteristic of the Indonesia labour market since the early 1970s.

The main reason for the recent importance of minimum wages has been that the government has strongly pursued a minimum wage policy. The levels of minimum wages were increased very significantly, particularly after 1990. This raises concerns whether further large increases in minimum wages will have positive or negative effects on employment. Therefore, the purpose of this study is to evaluate the impact of the increases in minimum wages on various groups of workers in Indonesia.

To provide a framework for this study, theoretical models and the main empirical studies on the links between minimum wages and employment are presented. Some models suggest that increases in the minimum wage that lead to increases in market wages, and which do not correspond to increases in productivity, should have the effect of reducing employment, increasing labour supply and increasing unemployment. Most of the available empirical evidence on the effects of increases in the minimum wages on employment supports this prediction. On the other hand, the alternative models suggest that the link between minimum wages and employment is not automatically negative, and might even be positive.

This study examines data for 26 provinces, covering the period from 1988 to 1999. A focus is on the specific groups of workers within the urban formal sector, such as females, youth workers, and less educated workers, which have been identified in many previous studies as the groups most vulnerable to changes in minimum wages. Graphical analysis is used to illustrate the possible employment effect in several provinces with the largest urban formal employment. Then, using statistical tools, the study explores a number of alternative models that have been used in the literature for quantifying this employment effect.

The paper is organised as follows. Chapter Two briefly introduces the theoretical framework and the main empirical studies on the links between minimum wages and 
employment. Chapter Three illustrates the labour market situation and the practice with respect to minimum wages in Indonesia. Chapter Four investigates the employment effect of the minimum wage in Indonesia by using graphical analysis and statistical tools. Chapter Five summarises this study.

\section{LITERATURE REVIEW}

\subsection{Introduction}

This chapter briefly introduces the theoretical framework and the main empirical studies on the links between minimum wages and employment. It has two main sections. The first section examines the predictions of a number of the economic models of minimum wage effects. The first three models consider a competitive labour market in which the available supply of labour is homogeneous. The models suggest that increases in the minimum wage that lead to increases in wages, and which do not correspond to increases in productivity, should have the effect of reducing employment, increasing labour supply and increasing unemployment. This presentation is followed by an outline of alternative models (monopsony, efficiency-wage) which suggest that the link between minimum wages and employment is not automatically negative, and might even be positive.

The second section of this chapter reviews the empirical evidence on the impact of increases in the minimum wage on employment levels. In some studies, the empirical evidence has shown that increases in the minimum wage tend to reduce employment rates. But other studies claim that minimum wage increases do not necessarily lead to less employment, and may even create more jobs for the unskilled. The main results of these studies will be presented in this section.

\subsection{The Theoretical Models}

\subsubsection{Competitive Labour Market Model}

The most basic model of the consequences of minimum wage legislation on employment focuses on a single competitive labour market. In this model, many firms compete for workers while a large number of individuals compete for jobs. Neither a firm nor an individual can affect the equilibrium wage. The available supply of labour is assumed homogeneous. Figure 1 depicts this idealised market. 
Figure 1

The Competitive Labour Market

$$
\text { Wages }
$$

Labour Supply

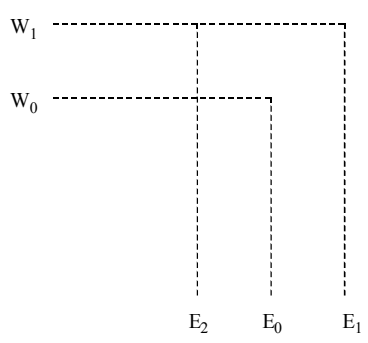

Labour Demand

Employment

The amounts of labour supplied and demanded (measured on the horizontal axis) depend on the level of the wage (measured on the vertical axis). The downward-sloping curve represents the marginal productivity of labour. For a given stock of the other factors of production, the contribution to output of each additional worker is assumed to decrease as the total number of workers increases. This curve can be interpreted as a labour demand schedule. The upward-sloping curve represents the alternative earnings of the workers and can be interpreted as a labour supply schedule.

Competitive forces are predicted to operate so that the wage tends towards the equilibrium value, $\mathrm{W}_{0^{\prime}}$, the wage rate corresponding to the point of intersection of the supply and demand curves. The initial employment is $\mathrm{E}_{0}$. A minimum wage is simply a wage imposed on the market above the equilibrium wage of $W_{0}$. Assume this wage is set at $W_{1}$. Following the introduction of the minimum wage of $\mathrm{W}_{1}$, employment falls to $\mathrm{E}_{2}$. At this higher wage, more workers will offer themselves for jobs, so labour supply will increase to $E_{1}$. Therefore, the effect of the minimum wage is to reduce employment and to create unemployment of $\mathrm{E}_{1}-\mathrm{E}_{2}$.

This analysis shows there are three major effects of a minimum wage: on employment, on labour supply and on unemployment. There are also effects on the total earnings of labour. All these effects depend on the crucial own-wage elasticities of demand and supply. These elasticities have been the focus of much of the empirical literature that is reviewed below. 


\subsubsection{Two-Sector Model}

This model extends the simple model outlined above by considering two sectors of the economy, one being covered by the minimum wage and one that is not covered by the minimum wage. The later sector is termed the uncovered sector.

When the minimum wage is introduced higher than the equilibrium wage in the covered sector, the workers displaced by the minimum wage move to the uncovered sector. ${ }^{1}$ This flow of workers will shift the supply curve in the uncovered sector to the right, thereby placing downward pressure on wages in this sector. If we apply the predictions of traditional economic theory, employment in the uncovered sector would increase. It is important to note that unemployment need not result from the minimum wage in this model: rather those who would otherwise have been unemployed in the covered sector can move to the uncovered sector, where the wage can adjust to clear the market.

Brown, Gilroy and Kohen (1982) argued that those displaced from the covered sector do not automatically become employed in the uncovered sector. As wages in the uncovered sector fall, some of those displaced by the minimum wage, as well as a part of those who were originally employed in the uncovered sector, may decide not to work in the uncovered sector because the wage there is less than their reservation wage. Rather they may continue to search for employment in the relatively high wage covered sector. This phenomenon of queuing or "wait unemployment" is analysed in section 2.2.3.

In developed countries, where the coverage of minimum wage appears high, the singlesector model might be appropriate. For developing countries, however, the two-sector model will be more relevant. In these countries only a small share of workers sell their services in a regulated, "formal" sector, subject to a mandated minimum wage. The remainder work in an unregulated, uncovered, "informal" sector, where wages are determined by the market (Packard, 2001, p.4). In the context of Indonesia, for example, the covered and uncovered sectors would refer to a distinction on the basis of employment status. The minimum wage rates and covered sector apply only to employees, while the large proportion of workers who work outside of the wage sector ${ }^{2}$, non-employee workers ${ }^{3}$, can be considered as members of the uncovered sector. There is also the mobility between these two sectors that is required of the two-sector model: Manning (2000) argued that employees in Indonesia are flexible enough to shift into informal activities as a response to a contraction in labour demand. More detail about the employment status in Indonesia is presented in Chapter 3.

\footnotetext{
${ }^{1}$ This assumes the absence of queuing for covered sector jobs, which is addressed in the next sub-section.

${ }^{2}$ In year 2000, workers in uncovered sector comprised $67 \%$ of total employment.

${ }^{3}$ Non-employee workers are: self-employed workers, employers with permanent workers and unpaid workers.
} 


\subsubsection{Two-Sector Model with Queuing for Covered-Sector Jobs}

Mincer (1976) formalised this model as an extension of the two-sector model. It provides the link that relates the effects of a minimum wage to unemployment. Hence Mincer's approach permits the introduction of a minimum wage to be analysed in terms of the effects on unemployment as well as on employment.

Mincer assumed that workers choose the sector that offers the highest expected wage. This is given by the probability of obtaining a job in a particular sector times the wage rate in that sector. The covered sector has a (minimum) wage $\left(W_{c}\right)$ greater than that in the uncovered sector $\left(\mathrm{W}_{\mathrm{u}}\right)$. But the probability of obtaining a covered sector job $\left(\mathrm{P}_{\mathrm{c}}\right)$ is less than one whereas an uncovered job can be obtained with certainty. Equilibrium in the model requires the equality of the expected wage in each sector. The imposition of a minimum wage that is higher than the equilibrium rate would make a certain amount of "waiting" for jobs in the covered sector worthwhile, thus creating a fixed amount of unemployment (Mincer, 1976, p. S89). Here unemployment is interpreted as queuing for covered-sector jobs.

According to Brown, Gilroy and Kohen (1982), this model makes the overly strong assumption that workers are unlikely to search for covered-sector jobs while employed in the uncovered sector. If the two sectors are geographically separate, this assumption would be realistic. In Indonesia, however, the coverage of the minimum wage depends on employment status (employee or non-employee) and so the markets will not be geographically separate. However, in many cases it appears as if uncovered sector jobs are employments of last resort for many workers. That is, the workers will work in one sector until circumstances force a change in employment type. They then will seek work in the other sector. Hence, activity (search or employment) in the alternative sectors is separated by a time dimension. This is consistent with the model outlined above.

\subsubsection{The Monopsony Model}

In the monopsony labour market, there is effectively only one buyer of labour, so its labour supply schedule is that of the labour market itself. As described in section 2.2.2, this labour supply function relates wage rates to the number of persons seeking employment. Since the labour supply is a positive function of the wages paid, the firms can attract and retain more workers only if they pay a higher wage.

Figure 2 depicts the equilibrium wage and employment in a monopsonistic labour market. 
Figure 2

The Monopsonistic Labour Market

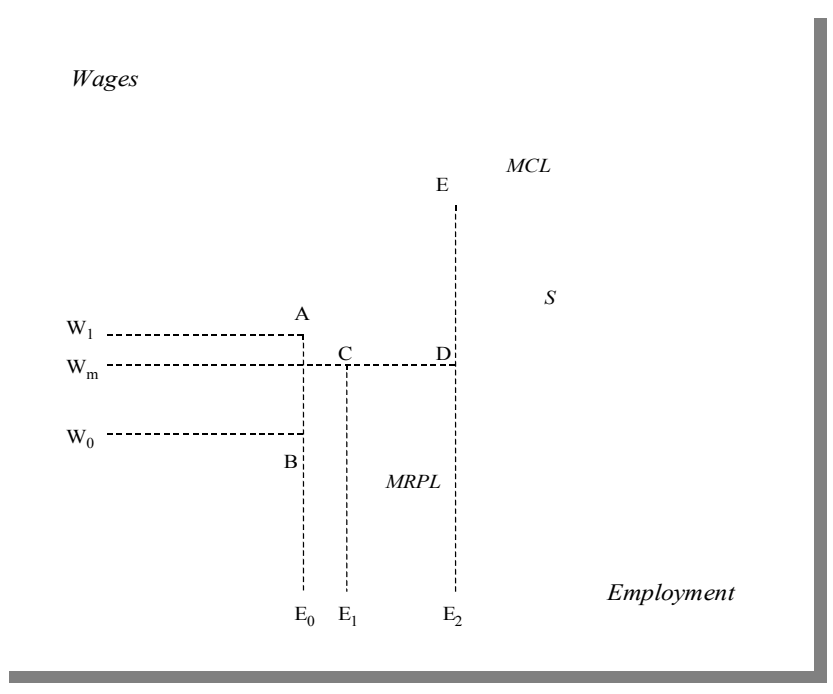

A monopsonist maximizes profit by hiring the amount of labour at $\mathrm{E}_{0}$, which equates the marginal cost of labour (MCL) to the marginal revenue product of labour (MRPL). Since there is only one firm hiring in this market, $\mathrm{E}_{0}$ is also total market employment.

Having chosen this level of employment, the monopsonist then offers the wage that will obtain $\mathrm{E}_{0}$ at minimum cost. This generates an equilibrium wage of $\mathrm{W}_{0}$. At this wage level, workers are paid less than their marginal value to the firm. This known as monopsonistic exploitation (Fleisher and Kniesner, 1984) and can be measured by the vertical distance AB.

Suppose that a minimum wage equal to $W_{m}$ is imposed on the labour market. With this minimum wage, the labour supply curve is the kinked line $W_{m} D S$. To the left of point $D$, the supply curve becomes a horizontal line at the value $\mathrm{W}_{\mathrm{m}^{\prime}}$, because workers are prevented from offering their services for less than the minimum wage. To the right of point $\mathrm{D}$, the supply curve follows $S$, because workers ask a wage rate above the minimum wage level $\left(W_{m}\right)$ in order to supply amounts of labour more than $\mathrm{E}_{2}$.

The firm's marginal cost curve becomes horizontal at the minimum wage for amounts of labour less than or equal to $\mathrm{E}_{2}$. When the quantity of labour exceeds $\mathrm{E}_{2}$, the marginal cost follows $W_{m} D$, then jumps up to $E$, and follows MCL again. With this new marginal cost of labour schedule, the monopsonist hires the amount of labour that equates its MRPL to its MC. This occurs at point $C$ and the equilibrium employment and wage become $E_{1}$ and $W_{m}$. 
The result is that a minimum wage between $W_{0}$ and $W_{1}$ will increase both the wage and employment above their monopsonistic values, $\mathrm{W}_{0}$ and $\mathrm{E}_{0}$. This conclusion can be taken as a possible explanation of the Card-Krueger findings that are reviewed in the empirical literature section below. They suggest that the imposition of the minimum wage can potentially increase employment at affected firms and in the industry as a whole (Card and Krueger, 1994, 1995).

\subsubsection{Efficiency-Wage Models}

Traditional neoclassical production theory views wages as determined by prices and labour productivity. However, in reality, compensation has complex incentive properties, and there may be causal links running not just from productivity to wages, but also from wages to productivity.

The central assumption of efficiency-wage models is that there is a benefit as well as a cost to a firm of paying a higher wage (Romer, 1996). According to Mankiw (1997), economists have proposed various theories to explain how wages affect worker productivity. One efficiency-wage theory holds that wages influence nutrition. A higher wage can increase workers' food consumption, and thereby cause them to be better nourished and more productive. A second efficiency-wage theory holds that high wages reduce labour turnover. By paying a high wage, a firm reduces the frequency of quits, thereby decreasing the time spent hiring and training new workers. A third theory holds that the higher are wages, the higher the average quality of the firm's work force. A fourth theory holds that a higher wage can increase workers' effort in situations where the firm cannot monitor them perfectly. All these theories indicate that the firm operates more efficiently if it pays its workers above the competitive equilibrium wage rate.

These efficiency-wage theories hold that high wages make workers more productive. As cited by Brown, Gilroy and Kohen (1982), it can be argued that if employers do not minimise costs, there is the possibility that they will respond to a minimum wage increase by raising the productivity of their operation to offset the increase. Wages above the average would increase incentives to work and lead to better economic performance, through lower absenteeism and better adaptation of workers.

\subsection{Overview of the Empirical Studies}

The theoretical effects of a minimum wage seem to be ambiguous. The competitive labour market model suggests that the introduction of a minimum wage that raises the wages 
of some workers would automatically reduce the employment prospects of that particular category of workers. This simple textbook 'proof' of the effect of a minimum wage seems to be what most people have in mind. A survey by Kearl, Pope, Whiting and Wimmer in 1979 showed that $90 \%$ of economists working at universities, in government and in the business sector in the United States generally agreed, or agreed with provisions, with the statement that 'A minimum wage increases unemployment among young and unskilled workers.' The monopsony and efficiency wage models, however, suggest that the link between wages and employment is not automatically negative, and might be positive. These ambiguous theoretical conclusions are also reflected in the available empirical evidence.

In a comprehensive survey of the empirical literature on minimum wages from the United States, Brown, Gilroy and Kohen (1982) concluded that the empirical evidence was generally in accord with the standard theory. To examine the effects of the minimum wage on teenagers, two sorts of studies were surveyed, namely, time-series studies of teenagers and youth and cross-section studies of teenagers. It is important to note the restriction of the main focus of the Brown et al. (1982) survey: they examine teenagers and youth as these are among the lowest paid workers and so minimum wages are more likely to be effective in these employment markets. ${ }^{4}$

(i) Time-Series Studies of Teenagers and Youth

Time series studies make use of regression techniques to isolate the independent impact of changes over time in minimum wages on employment. Brown et al. (1982) synthesised the results of 25 previous time series studies conducted up to 1981, most of which focused on the teenage labour market. The studies used a single equation model of the type:

$$
Y=f\left(M W, D, X_{1} \ldots . X_{n}\right)
$$

where the dependent variable $\mathrm{Y}$ is a measure of labour force status. The independent variables include MW as a measure of the minimum wage, D as an aggregate demand (business cycle) variable to account for changes in the level of economic activity, and $\mathrm{X}_{1} \ldots \mathrm{X}_{\mathrm{n}}$ representing a host of other exogenous explanatory variables to control for labour supply, school enrollment, participation in the armed forces, and the like.

The key variable, the minimum wage, has generally been measured by the ratio of the nominal legal minimum wage to average hourly earnings weighted by coverage, the socalled Kaitz Index. The weight applied in this calculation is the number of persons employed in the specific group analysed as a proportion of total employment.

\footnotetext{
4 An effective minimum wage is one that is imposed above the market clearing wage. A minimum wage imposed below the market clearing wage, as might be the case for older or skilled workers, is said to be ineffective.
} 
The main summary finding from these time-series econometric studies is that a 10 percent increase in the minimum wage reduces employment among teenagers by 1 percent to 3 percent, holding other factors constant. Table 1 below is adapted from Brown et al.'s (1982) literature review.

Table 1

Estimated Impact of a 10 Percent Change in the Minimum Wage on Teenagers 16-19 Years

\begin{tabular}{|clcc|}
\hline NO & \multicolumn{1}{|c|}{ STUDY } & PERIOD & $\begin{array}{c}\text { CHANGE IN } \\
\text { EMPLOYMENT (\%) }\end{array}$ \\
\hline 1. & Kaitz (1970) & $1954-1968$ & -0.98 \\
\hline 2. & Kosters and Welch (1972) & $1954-1968$ & -2.96 \\
\hline 3. & Kelly (1975) & $1954-1968$ & -1.20 \\
\hline 4. & Kelly (1976) & $1954-1974$ & -0.66 \\
\hline 5. & Gramlich (1976) & $1948-1975$ & -0.94 \\
\hline 6. & Hashimoto and Mincer (19.70) & & \\
\hline & and Mincer (1976) & $1954-1969$ & -2.31 \\
\hline 7. & Welch (1976) & $1954-1968$ & -1.78 \\
\hline 8. & Ragan (1977) & $1963-1972$ & -0.65 \\
\hline 9. & Mattila (1978) & $1947-1976$ & -0.84 \\
\hline 10. & Freeman (1979) & $1948-1977$ & -2.46 \\
\hline 11. & Wachter and Kim (1979) & $1962-1978$ & -2.52 \\
\hline 12. & Iden (1980) & $1954-1979$ & -2.26 \\
\hline 13. & Abowd and Killingsworth (1981) & $1954-1979$ & -2.13 \\
\hline 14. & Betsey and Dunson (1981) & $1954-1979$ & -1.39 \\
\hline 15. & Boschen and Grossman (1981) & $1948-1979$ & -1.50 \\
\hline 16. & Brown, Gilroy and Kohen (1981) & $1954-1979$ & -0.96 \\
\hline 17. & Hamermesh (1981) & $1954-1978$ & -1.21 \\
\hline 18. & Ragan (1981) & $1963-1978$ & -0.52 \\
\hline
\end{tabular}

Source: Brown, Gilroy and Kohen (1982, pp.498 and 504), Tables 1 and 3

All studies find a negative employment effect for all teenagers together. In addition, the elasticity ${ }^{5}$ signs are almost exclusively negative for the various age-sex-race subgroups considered. The other consistent finding is the unemployment effects of the higher minimum wage are considerably weaker than the disemployment effects because of the withdrawal from the labour force by teenagers in response to a decline in job-prospects. This suggests there is a form of "uncovered" sector for teenagers. It takes the form of the schools sector and non-participation in either the labour market or the schools sector. ${ }^{6}$

5 The elasticity indicates the proportional change in employment, given a proportional change in the minimum wage.

6 In 1999, the number of people aged 15-24 in Indonesia who were not working because they were attending school was $10,733,276(27.42 \%$ of all people aged $15-24)$ and the number who were not involved in either the labour market or the schools sector was $8,209,731$ (20.97\% of all people aged $15-24)$. 
(ii) Cross-Section Studies of Teenagers

The cross-section approach involves comparing states or metropolitan areas which differ in the relative importance of their minimum wage. This could be because of variations in the minimum wages across areas (due to State laws) or because of variations in the market wages across areas (due, for instance, to differing levels of economic activity). The survey covered studies that focus on differences in State laws and also those of the effect of the Federal minimum wage on different states.

Representative estimates of the employment effects of a 10 percent change in the minimum wage based on these cross-section studies are presented in Table 2 below.

Table 2

Estimated Impact of a 10 Percent Change in the Minimum Wage on Teenagers 16-19 Years

\begin{tabular}{|llcc|}
\hline NO & \multicolumn{1}{c}{ STUDY } & YEAR & $\begin{array}{c}\text { CHANGE IN } \\
\text { EMPLOYMENT (\%) }\end{array}$ \\
\hline 1. & Welch and Cunningham (1978) & 1970 & -4.82 \\
\hline 2. & Freeman (1979) & 1970 & -3.22 \\
\hline 3. & Cunningham (1981) & 1970 & \\
\hline & Employment & & -0.24 \\
& Full-time Equivalent Employment & & 0.15 \\
\hline
\end{tabular}

Source: Brown, Gilroy and Kohen (1982, pp.510 and 511), Tables 4 and 5

With a smaller number of studies, empirical studies using cross-sectional data produce a wider range of estimates than the time-series results. Most studies, however, suggest that a 10 percent increase in the minimum wage reduces employment rates among teenagers by about the 1-3 percent range that was found in the time-series studies.

This negative relationship between minimum rates of pay and employment levels established by Brown et al. (1982) in their early survey carries across to more recent studies. Deere, Murphy and Welch (1995), for example, investigated the employment effects of the more recent increases in the Federal minimum wage in the United States, from $\$ 3.35$ to $\$ 3.80$ on April 1, 1990 and then to $\$ 4.25$ on April 1, 1991. They compared changes in employment rates of high and low-wage populations. Table 3 below lists changes in employment rates relative to the 1989 levels. 
Table 3

Percentage of Low-wage Workers and

the Percentage Change in Employment/Population Ratios

Over Levels for April 1, 1989 - March 31, 1990

\begin{tabular}{|c|c|c|c|c|}
\hline \multirow[b]{2}{*}{ Group } & \multicolumn{2}{|c|}{ Men } & \multicolumn{2}{|c|}{ Women } \\
\hline & $\begin{array}{l}\text { Fraction } \\
\text { low-wage }\end{array}$ & $\begin{array}{c}\text { Employment } \\
\text { change }\end{array}$ & $\begin{array}{c}\text { Fraction } \\
\text { low-wage }\end{array}$ & $\begin{array}{c}\text { Employment } \\
\text { change }\end{array}$ \\
\hline Age: & & & & \\
\hline $15-19$ & 44.5 & -15.4 & 51.8 & -12.99 \\
\hline $20-24$ & 14.2 & -5.6 & 19.0 & -4.3 \\
\hline $25-64$ & 3.3 & -2.5 & 8.8 & -0.3 \\
\hline $65-69$ & 14.0 & -4.3 & 21.0 & +3.5 \\
\hline Race: & & & & \\
\hline Black & 11.0 & -4.8 & 16.9 & -3.4 \\
\hline White & 7.2 & -3.1 & 13.0 & -0.6 \\
\hline Asian & 5.4 & +0.7 & 9.3 & -0.3 \\
\hline Spanish ethnicity: & & & & \\
\hline Mexican & 15.6 & -4.8 & 21.9 & -5.5 \\
\hline Other Spanish & 8.8 & -3.3 & 16.4 & -0.7 \\
\hline Non Spanish & 7.1 & -3.2 & 12.9 & -0.8 \\
\hline $\begin{array}{l}\text { Years of school } \\
\text { completed: }\end{array}$ & & & & \\
\hline Less than 12 & 20.7 & -6.6 & 35.4 & -7.3 \\
\hline 12 & 6.0 & -4.0 & 13.5 & -2.2 \\
\hline More than 12 & 3.5 & -2.8 & 6.4 & -0.7 \\
\hline Marital status: & 15.1 & -4.4 & 18.4 & -3.2 \\
\hline Single & 2.7 & -2.4 & 9.0 & +0.7 \\
\hline Married & & & & \\
\hline States: & & & & \\
\hline 10 lowest-wage & 13.1 & -1.5 & 23.7 & +0.0 \\
\hline Middle-wage & 7.9 & -3.4 & 14.2 & -0.7 \\
\hline 10 highest-wage & 3.5 & -4.0 & 5.6 & -2.9 \\
\hline All & 7.5 & -3.2 & 13.3 & -1.1 \\
\hline
\end{tabular}

Source: Deere, Murphy and Welch (1995, p.235), Table 3 
The results in Table 3 show that the group with the highest percentage of low-wage workers (in italics) is also the group whose employment shows the greatest drop. For example, the age comparisons show that employment declines are greatest for those aged 15-19, since this group has the highest incidence of low wage workers. Comparisons across racial groups indicate that black workers, the group with the highest percentage of low-wage workers, experienced the largest employment losses. This emphasises the importance of the distinction between effective and ineffective minimum wages. A given minimum rate of pay will be effective for low wage earners only, and hence will have greater impact on the low-skilled sector of the workforce.

It can be seen that there are exceptions to this general finding, namely the gender and geographic splits. The employment rate of women does not fall relative to the rate of men and low-wage employment does not fall more in low-wage states than in higher-wage states. Deere, Murphy and Welch argued that the minimum wage responses are swamped by the broader trends of increasing labour-market participation of women and by the stronger employment growth in high-wage states than in low-wage states ${ }^{7}$. However, if men and women are viewed separately, the increases in the minimum wage coincide with shifts toward less employment for lower-wage workers within each gender. Similarly for the across-State comparisons that allow for gender effects, where it is found that employment of low-wage workers falls relative to those who typically earn more both in high-wage and low-wage states.

Although most economists believe that, consistent with the evidence reviewed above, increases in the minimum wage reduce employment among workers with little skill and experience, some studies question this conclusion. In September 1994, David Card and Alan Krueger published a study on minimum wages with a focus on the New Jersey minimum wage increase in 1992, where this State raised its minimum wage to $\$ 5.05$, while the neighbouring State of Pennsylvania kept the Federal rate of $\$ 4.25$. They examined the fast food industry as the leading employers of low wage earners and an industry that enforces the minimum wage. Their analysis was based on establishment surveys conducted prior to the increase in the minimum wage and after the minimum wage was increased. The first wave of the survey was conducted a little over a month before the scheduled increase in New Jersey's minimum wage. The second wave was conducted about eight months after the minimumwage increase. Table 4 summarises the levels and changes in average employment per store by state in their survey.

\footnotetext{
7 There was an employment expansion in the South and Southwest where wages were lower than in the Northeast, Upper Midwest, and West.
} 
Table 4

Average Employment per Store by State

Before and After the Rise in New Jersey Minimum Wage

\begin{tabular}{|l|c|c|c|}
\hline \multicolumn{1}{c|}{ Variable } & Store by State & \\
\cline { 2 - 4 } & $\begin{array}{c}\text { Pennsylvania } \\
\text { (PA) } \\
\text { (i) }\end{array}$ & $\begin{array}{c}\text { New Jersey } \\
\text { (NJ) } \\
\text { (ii) }\end{array}$ & $\begin{array}{c}\text { Difference, } \\
\text { NJ - PA } \\
\text { (iii) }\end{array}$ \\
\hline $\begin{array}{l}\text { 1. Full-Time-Equivalent (FTE) } \\
\text { employment before, all available } \\
\text { observations. }\end{array}$ & 23.33 & 20.44 & -2.89 \\
$\begin{array}{l}\text { 2. FTE employment after, all available } \\
\text { observations }\end{array}$ & 21.17 & 21.03 & -0.14 \\
$\begin{array}{l}\text { 3. Change in mean FTE employment } \\
\begin{array}{l}\text { 4. Change in mean FTE employment, } \\
\text { balanced sample of stores }\end{array}\end{array}$ & -2.16 & 0.59 & 2.76 \\
$\begin{array}{l}\text { 5. Change in mean FTE employment, } \\
\text { setting FTE at temporarily closed } \\
\text { stores to 0 }\end{array}$ & -2.28 & 0.47 & 2.75 \\
\hline
\end{tabular}

Source: Card and Krueger (1994, p.780), Table 3

Rows 1 and 2 of the table present data on full-time equivalent employment before (wave 1 of the survey) and after (wave 2 of the survey) the increases in New Jersey's minimum wage, from all available observations. The changes in average employment between waves 1 and 2 are shown in row 3 . An alternative estimate of the change is presented in row 4 : in this row, the computation of the change in employment is restricted to the subsample of stores that reported valid employment data in both waves (the balanced subsample). Row 5 presents the average change in employment in the balanced subsample, treating employment at temporarily closed stores in wave 2 as zero, rather than as missing.

After the rise in the minimum wage, stores in New Jersey grew relative to stores in Pennsylvania, with the relative gain being 2.76 FTE employees. When the analysis is restricted to the balanced subsample, the relative change is virtually identical (2.75) to that reported for the full sample, and only slightly smaller (2.51) when employment at temporarily closed stores in wave 2 is treated as zero. Thus this study indicated that employment actually expanded in New Jersey relative to Pennsylvania, where the minimum wage was constant. 
Card and Krueger also compared the low-wage ( $\$ 4.25$ per hour in wave 1 ) and highwage ( $\$ 5.00$ or more per hour in wave 1 ) stores in New Jersey before and after the new minimum wage. This comparison showed that employment expanded at the low-wage stores and contracted at the high-wage stores. This comparison provides a specification test of the validity of the Pennsylvania control group in that the minimum wage is less likely to be effective in the high wage stores in New Jersey and so the employment behaviour in these stores is expected to resemble that in the stores in Pennsylvania.

In some additional research that they conducted using data from other states, Card and Krueger found a positive correlation between a higher minimum wage and employment. The Card-Krueger study leads us to believe that employers demand more labour as its price rises.

According to Mankiw (1997), one possible explanation of this result is that firms have some market power in the labour market. As shown in section 2.3.4, a monopsonistic firm buys less labour at a lower wage than a competitive firm would. The monopsonistic firm reduces employment in order to depress the wage it has to pay. A minimum wage prevents the monopsonistic firm from following this strategy and so can increase employment. However, most economists are sceptical of the monopsony explanation, since most firms compete with many other firms for workers.

The Card-Krueger findings have sparked considerable controversy among labour economists and have generated much debate in academic and political circles. Their data have been criticized, and researchers working with better data have shown the result is reversed. A follow-up investigation by Neumark and Wascher (1995) showed that Card and Krueger collected their data incorrectly. In particular, the data collected by Card and Krueger appear to indicate greater employment variation over the eight-month period between their surveys than do payroll data. Moreover, even if the Card-Krueger data were correct, one can argue that their study searched for effects across too few industries and allowed too little time to elapse (Miller, 1995). Richard Berman of the Employment Policies Institute also disagreed with the methodology of the Card and Kruger study. He argued that the analysis should have focused on the number of hours worked instead of the number of employees (Berman, 1998).

In the context of Indonesia, Rama (2001) has attempted to assess the impact of minimum wage policy on the labour market. Based on the results of an econometric analysis of data from 27 provinces for the period from 1988 to 1995, minimum wage policies were shown to have had a modest impact on labour market outcomes. The starting point for his analysis was a basic equation of the type: 


$$
Z_{i t}=f\left(M W_{i t}\right)+\theta_{i}+\tau_{i}+\varepsilon_{i t}
$$

where $Z_{i t}$ is an economic outcome in province $i$ and year $t, M W_{i t}$ is the minimum wage in province $i$ and year $\mathrm{t}, \theta_{i}$ is a province-specific effect (e.g. infrastructure, natural resources, demography, etc.), $\tau_{i}$ is a year-specific effect (e.g. macroeconomic policies, external shocks, the investment climate, etc.) and $\varepsilon_{i t}$ is a stochastic disturbance.

In examining the impact of minimum wages on employment, Rama used a particular version of the basic equation above. Specifically, the economic outcome focused on by Rama was the ratio of employment to population, that is $\mathrm{Z}_{\mathrm{it}}=\mathrm{L}_{\mathrm{it}} / \mathrm{N}_{\mathrm{it}}$. The equation to be estimated was:

$$
L_{i t} / N_{i t}=b_{1}+b_{2}\left(M W_{i t} / R_{i t}\right)+\theta_{i}+\tau_{i}+\varepsilon_{i t}
$$

where $\mathrm{R}$ is an indicator of labour productivity. In his study, Rama used five different indicators of labour productivity: average earnings of urban labourers, average wage in manufacturing, labour costs per worker in large manufacturing, value added per worker in large manufacturing, and GDP per worker excluding oil and gas.

The elasticity in this specification can be calculated as $b_{2} \mu / \lambda$, where $\mu$ is the sample mean of $\mathrm{MW}_{\mathrm{it}} / \mathrm{R}_{\mathrm{it}}$ and is the sample mean of $\mathrm{L}_{\mathrm{it}} / \mathrm{N}_{\mathrm{it}}$. Rama's results show that the estimated elasticity of employment with respect to minimum wages is statistically significant in only one of the specifications, but it has the same sign (negative) in four of them and is close to zero in the fifth one. Therefore, it can be argued that higher minimum wages reduce wage employment in Indonesia.

Finally, Rama concluded that the doubling of the minimum wage in the first half of the 1990s led to an increase in average wages in the range of 5 to 15 percent, and a decrease in urban wage employment in the range of 0 to 5 percent. However, he suggested that while the disemployment effects appeared to be considerable in small manufacturing firms, employment may have actually increased in large firms. The workers in large firms are the winners from the increases in the minimum wage as their wages increase and there appears to be little risk that they will lose their jobs.

It is important to note that the main focus of Rama's study was the effects of increases in minimum wages for the whole aggregate of workers. However, as noted above, the impacts of increases in minimum wages on the various groups of workers are not the same, but fall mostly on the groups of workers who are sensitive to variations in parameters of a minimum wage regime. A focus on the specific groups of workers such as females, youth workers, and 
less educated workers would have been more informative. This issue becomes a consideration in the more current study by Suryahadi, et al. (2001).

Suryahadi, et al. (2001) use data from 26 provinces, covering the period from 1988 to 1999 , to analyse the impact of minimum wages on different groups of workers within the urban formal sector. They defined supply and demand for workers as follows:

$$
\begin{aligned}
& l^{S}=\alpha^{S}+\beta^{S} w+\gamma^{S} m(w)+\theta^{S} X \\
& l^{D}=\alpha^{D}+\beta^{D} w+\gamma^{D} m(w)+\theta^{D} X
\end{aligned}
$$

where $l^{S}$ and $l^{D}$ are labour supply and labour demand respectively, $w$ represents wages, $m$ represents the minimum wage, $X$ is a vector of labour supply shifters, $Y$ is a vector of labour demand shifters, while $\alpha, \beta, \gamma$ and $\theta$ are vectors of parameters.

In equilibrium, labour supply is equal to labour demand, and hence:

$$
l^{S}=\alpha^{S}+\beta^{S} w+\gamma^{S} m(w)+\theta^{S} X=l^{D}=\alpha^{D}+\beta^{D} w+\gamma^{D} m(w)+\theta^{D} X
$$

The reduced form solutions for wages and employment are:

$$
\begin{gathered}
w=\Lambda^{w}+\Omega^{w} m(w)+\Pi^{w} Y+\Sigma^{w} X \\
l=\Lambda^{l}+\Omega^{l} m(w)+\Pi^{l} Y+\Sigma^{l} X
\end{gathered}
$$

where $\quad \Lambda^{w}=\frac{\alpha^{D}-\alpha^{S}}{\beta^{S}-\beta^{D}}, \quad \Omega^{w}=\frac{\gamma^{D}-\gamma^{S}}{\beta^{S}-\beta^{D}}, \quad \Pi^{w}=\frac{\theta^{D}}{\beta^{S}-\beta^{D}}, \quad \Sigma^{w}=\frac{-\theta^{S}}{\beta^{S}-\beta^{D}}$,

$$
\Lambda^{l}=\frac{-\alpha^{S} \beta^{D}-\alpha^{D} \beta^{S}}{\beta^{S}-\beta^{D}}, \Omega^{l}=\frac{\beta^{S} \gamma^{D}-\beta^{D} \gamma^{S}}{\beta^{S}-\beta^{D}}, \quad \Pi^{l}=\frac{\beta^{S} \theta^{D}}{\beta^{S}-\beta^{D}}, \Sigma^{l}=\frac{-\beta^{D} \theta^{S}}{\beta^{S}-\beta^{D}}
$$

The parameters of main interest are $\Omega^{w}$ and $\Omega^{l}$, that is how the minimum wage affects wages and employment. The wage regression results indicate that the impact of minimum wages on average wages across the workforce is mixed. The wages of some workers are pushed up by minimum wages, while the wages of others are depressed by minimum wages. 
The results of employment regression indicate that the elasticity of total employment to the minimum wage is -0.112 and statistically significant. This implies that every 10 percent increase in real minimum wages will result in a 1.1 percent reduction in total employment. The coefficients for female, youth and less educated workers are also negative and statistically significant. The only group of workers which benefit from the minimum wage are whitecollar workers. A 10 percent increase in the real minimum wage is suggested to increase the employment of white-collar workers by 10 percent.

\subsection{Conclusion}

The theoretical models outlined in this chapter attempt to explain the correlation between the change in minimum wages and employment. According to the competitive models, an increase in the minimum wage that leads to an increase in wages, and which does not correspond to an increase in productivity, would have the effect of reducing employment.

Several criticisms have been advanced against this competitive model. The main one focuses on the fact that the firm is not always a price taker in the labour market (Ghellab, 1998). The alternative models (monopsony and efficiency-wage) suggest that the link between minimum wages and employment is not automatically negative, and might even be positive.

Most of the available empirical evidence on the effects of increases in the minimum wage on employment supports the standard theory that increases in the minimum wage tend to reduce aggregate employment rates and increase unemployment rates.

\section{THE MINIMUM WAGE IN INDONESIA}

\subsection{Introduction}

The first section of this chapter briefly illustrates the labour market situation in the rapidly changing Indonesian economy. Some key statistics on the Indonesian labour force are presented in this section. The second section describes the practice with respect to minimum wages in Indonesia. This includes an illustration of the minimum wage development and several key problems in its implementation. Finally, we end the chapter with some concluding remarks.

\subsection{The Labour Market Situation}

With a large labour force, a high unemployment rate and a rapidly expanding labour market, Indonesia has fairly unique economic circumstances. Manning $(1994,1998 b)$ describes 
the labour market in Indonesia as having low wages, long working hours, harsh labour management, poor working conditions, utilisation of under legal working age workers, and high rates of informalisation compared with other Asian countries. Table 5 presents some recent labour force characteristics for Indonesia.

Table 5

The Indonesian Labour Force Characteristics

Years 1996-1999

\begin{tabular}{|c|c|c|c|c|}
\hline CHARACTERISTICS & 1996 & 1997 & 1998 & 1999 \\
\hline Size of labour force (millions) & 88.2 & 89.6 & 92.7 & 94.8 \\
\hline Labour force participation rate $(\%)$ & 66.9 & 66.3 & 66.9 & 67.2 \\
\hline Female labour force ( $\%$ of the total labour force) & 38.5 & 38.3 & 38.8 & 38.4 \\
\hline Youth labour force $(\% \text { of the total labour force })^{\mathrm{a}}$ & 22.3 & 21.5 & 21.3 & 21.3 \\
\hline Less educated labour force ( $\%$ of the total labour force) ${ }^{b}$ & 78.8 & 77.9 & 75.8 & 76.3 \\
\hline
\end{tabular}

a: aged 15-24 years old

b: no schooling, unfinished primary, primary, lower secondary

Source: Badan Pusat Statistik /BPS (Central Bureau of Statistics of Indonesia)

The Indonesian labour force grew from 88,186,772 in 1996 to $94,847,178$ in 1999 (7.6\% growth). The labour force participation rate was relatively stable between 66 and 68 percent, suggesting that much of the growth in the labour force is due to growth in the population. The proportion of female and youth labour force also did not change much during the period reviewed. The female labour force varied a little, between 38 and 39 percent of all labour force participants. Similarly, the youth labour force fluctuated between 21 and 23 percent of all labour force participants. It is apparent from the table that there is a large proportion of less educated workers in labour market. However, this proportion decreased from 78.8\% in 1996 to $76.3 \%$ in 1999 .

Indonesia is also undergoing rapid structural transformation from agriculture into manufacturing and services. This transformation, however, has been associated with employment patterns that have changed less rapidly than those of output. The reasons behind this are primarily the slow rate of labour movement out of low productivity sectors, especially agriculture, and multiple jobs holding across sectors in the process of the shift out of agriculture (Hill 1996, p. 21). Figure 3 shows the distribution of workers across the main sectors.

It is clearly apparent from Figure 3 that the agricultural sector accounts for the largest share of employment in Indonesia. However, between 1996 and 1997, there was a redistribution of the share of employment away from agriculture and towards the 
Figure 3

The Distribution of the Work Force

Years 1996-1999

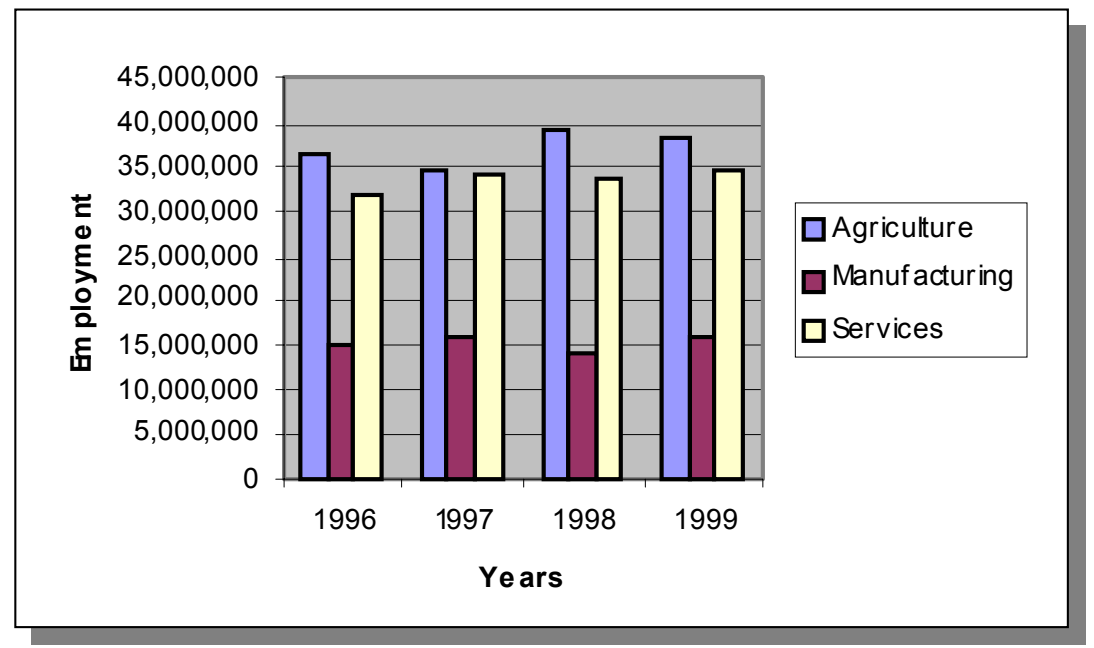

Source: Badan Pusat Statistik /BPS (Central Bureau of Statistics of Indonesia)

manufacturing and services sectors. Thus employment in agriculture fell from 36.5 million (43.5\% of total employment) in 1996 to 34.8 million (40.7\%) in 1997. During the economic crisis that affected the Asian region in 1997, workers in the manufacturing and services sectors who lost their jobs moved to the rural region and worked on the farms. This phenomenon increased agriculture's employment to 39.4 million (45.0\%) in 1998, while the employment of manufacturing and services decreased from 16.3 million $(19.1 \%)$ and 34.3 million (40.2\%) in 1997 to 14.3 million (16.3\%) and 34.0 million (38.8\%) in 1998. When the economy started to recover in 1999, employment in the manufacturing and services sectors increased to 15.8 million (17.8\%) and 34.6 million (39.0\%), respectively.

The impact of the economic crisis on employment in Indonesia was, in fact, less than had been expected. The International Labour Organisation (ILO) had predicted that perhaps as many as 10-14 million people would find themselves without jobs in 1998 (Cameron, 1999). However, the actual employment loss was more likely around 2 million ${ }^{8}$. The key explanations for this better than expected outcome are: the capability of people to find a new job after being cut back from wage employment, and the willingness of employees to accept lower wages, accept shorter work hours and obtain fewer employee benefits (Booth 1999, Manning 2000). Thus, there has been high flexibility in labour market adjustment combined with disobedience of employers toward minimum wage legislation, and low enforcement of

8 The number of people who left their jobs between August 1997 and August 1998 is 4,279,000. Of these, 51.1\% or $2,188,000$ were finding new jobs, of which $35.2 \%$ were in wage-jobs and $64.8 \%$ in non-wage jobs. 
the legislation that further weakens the bargaining power of workers such that they have no better choice than to accept wages below the legal rate. Therefore, regarding this labour market situation, discussion about the minimum wage in Indonesia and its impact on employment is of considerable interest.

\subsection{The Minimum Wage in Practice}

Minimum Wage Regulation was first introduced in Indonesia in the early era of the New Order Regime ${ }^{9}$, when economic activity was still dominated by home industries, and small and middle sized firms. The objective of this regulation was as a measure that would supposedly protect workers' interests, raise labour productivity, reduce widespread corruption and stimulate economic activity through a spending effect (Manning, 1993). At that time, the minimum wages were set for construction workers on government projects in Jakarta, and then applied to all workers in general and for other regions.

Since the middle of the 1980s, new legislation was established to regularise the haphazard system of minimum wages that had been in force in most regions (Rama, 2001). The government set the minimum wages with reference to the cost of living, labour market conditions and Minimum Physical Need/KFM (Kebutuhan Fisik Minimum). The KFM is measured by the estimation of a worker's minimum need in 4 main groups of consumption bundles: food, housing, clothing and a selected other items group. Each group contains a range of items that are considered vital for a single worker to live adequately.

In 1996, the KFM was adjusted with a wider range of consumption bundle and recognised as a Minimum Living Need/KHM (Kebutuhan Hidup Minimum) that represents a higher standard of living than KFM. ${ }^{10}$ The KHM bundle consists of 43 items: 11 items in the food group, 19 items in the housing group, 8 items in the clothing group and 5 items in the selected other items group. The improvement of the KHM always becomes a target for policy practitioners in the field of employment management.

The minimum wages are determined differently among the provinces in Indonesia. The background behind this policy was the difference of economic structure of the main groups of islands (Inkiriwang, 2001). It can be seen from the data in 2000 that among the groups of islands in Indonesia, Java, Bali and Sumatera have dominated economy activity, accounting for about $80 \%$ of Indonesia's GDP and also of the country's population. The table below describes the distribution of population and GDP in Indonesia.

9 The New Order Regime from 1966 until 1998, under Soeharto, acted as a 'state authoritarian corporatist and exclusionary system' with high state control (Ford, 1999).

10 As cited from "Upah Minimum Sebuah Kajian Tentang Dampaknya Terhadap Penciptaan Lapangan Kerja di Masa Krisis" (Minimum Wage, An Analysis of the Impact of Job Creation during Crisis Era). 
Table 6

Distribution of Population and GDP by Main Island Group (\%)

Year 2000

\begin{tabular}{|l|c|c|}
\hline ISLAND GROUP & POPULATION & GROSS DOMESTIC PRODUCT \\
\hline Sumatera & 20.96 & 22.05 \\
\hline Java \& Bali & 60.71 & 59.56 \\
\hline Kalimantan & 5.41 & 10.17 \\
\hline Sulawesi & 7.09 & 4.49 \\
\hline Others & 5.82 & 3.73 \\
\hline TOTAL & 100 & 100 \\
\hline
\end{tabular}

Source: Badan Pusat Statistik /BPS (Central Bureau of Statistics of Indonesia)

In practice, however, until the late 1980s the minimum wage policy was ineffective. Minimum wages were introduced largely for 'cosmetic reasons' (Manning, 1998a, p.116). In large part this was because the government tightly controlled the labour movement by recognising only a single trade union confederation ${ }^{11}$ (Lambert 1993, Nusantara 1995, Storey 2000). In contrast, in other countries, such as Australia, trade unions are a crucial part of the wage setting process (Miller \& Mulvey, 1989). The strong political dictatorship in Indonesia during the New Order Regime prevented unionism from realizing its potential for autonomous action (Hess, 1990) and furthermore the political considerations were frequently more important than economic demands in unions (Hess 1997, Sidik \& Iskandaryah 1993, Suwarno \& Elliot 2000). As a result, Manning (1994) pointed out there was little effective direct government or union involvement in the setting of wages.

Moreover, disobedience of employers in Indonesia with respect to the payment of minimum wages, low sanctions imposed on offenders ${ }^{12}$ and mild enforcement of legislation by government have all meant that this policy has had little impact on the labour market (Manning 1993, Gall 1998). There was also a lack of regular and genuine inspection, with only 700 labour inspectors to monitor 147,000 companies in 1990, and there are routinely bribes to ignore malpractices (Gall 1998, p. 367). Hess (1997, p. 37) noted that the reason employers often pay less than the minimum wage was the widespread nature of a "patronclient relationship ${ }^{\prime 13}$ in employment relations. This gives employers the opportunity to gain

11 This union was not designed to represent workers in Indonesia, but it was designed to control their movement (Gall, 1998, p. 366)

12 As cited in Gall (1998, p. 367), penalties for violation of labour laws are too low (three months jail sentence and SUS 55 fine) to have any punitive effect.

13 This relationship is influenced by Javanese culture, with an emphasis on formal behaviour and acceptance of authority (Hess 1997, p. 37). 
wage flexibility and has undermined the protection employees derive, in principle, from state regulation of minimum wages. Patron-client relationships are very strong in the public sector due to the major domination of Javanese officers in this sector ${ }^{14}$.

There was a turning point for Indonesian industrial relations in 1987. At this time there was international pressure towards Indonesia, charging Indonesia with breaching international agreed labour standards by allowing only one government controlled union. This international pressure has had a dramatic impact on the development of independent unionism (Gall 1998, Abdullah and Etty 1995, Lambert 1993). The development of independent unionism also was supported by several complaints under the Generalised Scheme of Preferences $(\mathrm{GSP})^{15}$, which threatened to deprive Indonesia of low tariffs on its exports to the US market (Hess 1997, Rama 1996). These independent unions, supported by Non Governmental Organizations (NGOs) and the Commission on Human Rights ${ }^{16}$ have presented a major challenge for the government ${ }^{17}$ and have been very important in the fight for better terms of employment of workers ${ }^{18}$. The waves of strikes ${ }^{19}$ with wages as a major cause have placed significant pressure on the government to increase wages. The result has been a series of gradual increases in the minimum wage (Manning 1998 , KOMPAS 2000). The strike indeed has had such an impact that $90 \%$ of factories are now paying the minimum wage ${ }^{20}$ (Gall 1998, p. 371).

The importance of minimum wages as a key element of economic and social policy has been a consideration in the recent years when the government has strongly pursued a minimum wage policy. The levels of minimum wages were increased very significantly (Inkiriwang, 2001). This situation has been pursued because of the growing realization by workers of the big differences in wealth between themselves and their employers, supported by the activities of the NGOs and the willingness of journalists to cover these stories (Gall, 1998, p. 371). Table 7 below illustrates the minimum wage development in Indonesia.

14 But this patron-client relationship has been limited by foreign and Chinese ownership of enterprise in the private sector.

15 The General System of Preferences is a facility under which Indonesia has a concession on export activity to the United States and the removal of this will make Indonesian products more expensive in the United States.

16 This was established in 1993 as a response to international pressure in 1987.

17 The Manpower Minister and other government officers did, however, indicate their opposition to this development and took the decision not to recognise formally or give support (financial or other) to the new organisation (Manning, 1993, p.79).

18 Unfortunately, there is much evidence of the existence of repression and restrictive regulations imposed on the independent unions (Beth 2001 (a)(b), Manning 1998b).

19 There are 188 cases of labour strikes during 1985 and 1987 (data source: http://laborsta.ilo.org).

20 The power of unionism in Indonesia as a threat for the employers to pay higher wages has become significant, as in the case of Australia (Australia's case is discussed in Miller, Mulvey \& Neo, 1997). 
Table 7

Minimum Wages, Inflation and KHM

Years 1997-1999

\begin{tabular}{|c|c|c|c|c|c|c|}
\hline $\begin{array}{c}\text { YEARS } \\
(\mathbf{1})\end{array}$ & $\begin{array}{c}\text { MW } \\
\mathbf{( 2 )}\end{array}$ & $\begin{array}{c}\text { GROW } \\
\mathbf{( 3 )}\end{array}$ & $\begin{array}{c}\text { INFLATION } \\
\mathbf{( 4 )}\end{array}$ & $\begin{array}{c}\mathbf{( 3 )}-\mathbf{( 4 )} \\
\mathbf{( 5 )}\end{array}$ & $\begin{array}{c}\text { KHM } \\
\mathbf{( 6 )}\end{array}$ & $\begin{array}{c}\text { MW/KHM } \\
\mathbf{( 7 )}\end{array}$ \\
\hline 1997 & 135,676 & & 11.1 & & 141,953 & 95.6 \\
\hline 1998 & 155,719 & 14.8 & 77.6 & -62.8 & 205,112 & 75.9 \\
\hline 1999 & 182,391 & 17.1 & 2.0 & 15.1 & 252,996 & 72.1 \\
\hline
\end{tabular}

Sources: Badan Pusat Statistik/BPS (Central Bureau of Statistics of Indonesia) and Bank Indonesia (Central Bank of Republic of Indonesia)

It can be seen from Table 7 that minimum wages have been increased significantly in nominal terms (columns 2 and 3). The minimum wage was almost at the level of the KHM (95.6\%) in 1997, and was increased by $14.8 \%$ in 1998 . However, in real terms it fell drastically in 1998 due to the high inflation (77.6\%) that swept the country during the economic crisis. In 1998, the inflation rates in the provinces' capital cities ranged from $61.8 \%$ to $97.8 \%$. In 1999 , the inflation rate was quite low (2.0\%), but the cost of the components of the KHM was high. ${ }^{21}$ As a result, the minimum wage was only $72.1 \%$ of the KHM. Moreover, the ratio of minimum wage to KHM was smaller in 1999 than in 1998, which indicated a decreasing level of workers' welfare. Table 8 presents the ratio of minimum wage to KHM by province in 1999.

The table clearly shows that minimum wages were below the KHM in each province. This is may be the reason why governments increased the regional minimum wages every year. The highest ratio of minimum wage to KHM was in Sumatera Utara $(80.5 \%)$ and the lowest ratio was in DI Aceh (55.6\%).

As noted in section 2.2.2, many workers are not covered by minimum wage legislation, particularly in developing countries. In the context of Indonesia, minimum wage rates only apply to employees. ${ }^{22}$ Coverage does not embrace self-employed workers ${ }^{23}$, employers with permanent workers ${ }^{24}$, and unpaid workers. ${ }^{25}$ This segment

21 The high cost of the KHM was because of the impact of price increases in the previous year.

22 An employee is a person who works for another person or an institution for pay in cash or in kind.

23 A self-employed worker is a person who works at her/his own risk with/without the assistance of his/her family members or temporary workers.

24 An employer with permanent workers is a person who does his/her business assisted by paid permanent workers.

25 An unpaid worker is a person who works without pay in an economic enterprise operated by other members of the family, relatives or neighbours. 
Table 8

The Minimum Wages and KHM by Province

Year 1999

\begin{tabular}{|c|c|c|c|}
\hline PROVINCES & MINIMUM WAGES & KHM & RATIO (\%) \\
\hline DI Aceh & 171,000 & 307,603 & 55.6 \\
\hline Sumatera Utara & 210,000 & 261,000 & 80.5 \\
\hline Sumatera Barat & 160,000 & 251,712 & 63.6 \\
\hline Riau & 242,000 & 355,515 & 68.1 \\
\hline Jambi & 150,000 & 215,463 & 69.6 \\
\hline Sumatera Selatan & 175,500 & 251,586 & 69.8 \\
\hline Bengkulu & 150,000 & 210,162 & 71.4 \\
\hline Lampung & 160,000 & 220,500 & 72.6 \\
\hline DKI Jakarta & 231,000 & 351,263 & 65.8 \\
\hline Jawa Barat & 208,750 & 330,949 & 63.1 \\
\hline Jawa Tengah & 153,000 & 235,750 & 64.0 \\
\hline DI Yogyakarta & 130,000 & 227,064 & 57.3 \\
\hline Jawa Timur & 170,500 & 251,371 & 67.8 \\
\hline Bali & 176,500 & 288,000 & 61.3 \\
\hline Nusa Tenggara Barat & 145,000 & 257,150 & 56.4 \\
\hline Nusa Tenggara Timur & 143,000 & 237,425 & 60.2 \\
\hline Kalimantan Barat & 175,000 & 255,707 & 68.4 \\
\hline Kalimantan Tengah & 195,000 & 335,442 & 58.1 \\
\hline Kalimantan Selatan & 166,000 & 233,721 & 71.0 \\
\hline Kalimantan Timur & 194,000 & 317,704 & 61.1 \\
\hline Sulawesi Utara & 155,000 & 248,706 & 62.3 \\
\hline Sulawesi Tengah & 150,000 & 240,000 & 62.5 \\
\hline Sulawesi Selatan & 148,000 & 257,035 & 57.6 \\
\hline Sulawesi Tenggara & 160,000 & 254,250 & 62.9 \\
\hline Maluku & 180,000 & 223,968 & 80.4 \\
\hline Papua & 225,000 & 331,579 & 67.9 \\
\hline
\end{tabular}

Source: Badan Pusat Statistik /BPS (Central Bureau of Statistics of Indonesia)

of employment can be considered as an uncovered sector. Table 9 describes the main employment states in Indonesia.

The fraction of employees is only around 33\% of total employment (35.45\% in 1997, $32.85 \%$ in $1998,33.08 \%$ in 1999 , and $33.03 \%$ in 2000). The remainder of employed persons are excluded from coverage. Not surprisingly, these groups of workers are often among the lowest paid in the workforce. 
Table 9

Employed Persons 15 Years of Age and Over by Main Employment Status 1997, 1998 and 1999

\begin{tabular}{|l|c|c|c|c|}
\hline Main Employment Status & $\mathbf{1 9 9 7}$ & $\mathbf{1 9 9 8}$ & $\mathbf{1 9 9 9}$ & $\mathbf{2 0 0 0}$ \\
\hline 1. Employee & $30,277,787$ & $28,805,421$ & $29,383,548$ & $29,670,366$ \\
\hline 2. Self-Employed & $37,847,519$ & $40,213,397$ & $40,622,280$ & $39,973,785$ \\
\hline $\begin{array}{l}\text { 3. Employer with Permanent } \\
\text { Workers }\end{array}$ & $1,466,471$ & $1,525,625$ & $2,552,803$ & $2,043,169$ \\
\hline 4. Unpaid Worker & $15,813,752$ & $17,128,006$ & $16,258,228$ & $18,136,703$ \\
\hline Total & $85,405,529$ & $87,672,449$ & $88,816,859$ & $89,824,023$ \\
\hline
\end{tabular}

Source: Badan Pusat Statistik /BPS (Central Bureau of Statistics of Indonesia)

\subsection{Conclusion}

Indonesia has a large labour force, a high unemployment rate and a rapidly expanding labour market. The Indonesian labour market comprises a large proportion of workers who are very vulnerable to changes in labour market conditions. These groups include females, youth workers and less educated workers. Of particular note is the fact that less educated workers account for about $77 \%$ of the Indonesian labour force.

With these unique economic circumstances, the importance of minimum wages has been a major consideration in the recent years after being largely symbolic for almost two decades (Rama, 2001). This was happened when the government strongly pursued a minimum wage policy. The levels of regional minimum wages have been increased significantly in nominal terms. However, the economic crisis that started in 1997 and deepened in 1998 has reduced the minimum wage in real terms, and this means there have been decreases in the level of workers' welfare.

As is the case for most developing countries, only a small proportion of the workforce in Indonesia is covered by the minimum wage legislation, since the minimum wage rates apply only to employees. A significant proportion of workers, the non-employees, are not covered by minimum wages.

\section{THE EFFECT OF MINIMUM WAGES ON EMPLOYMENT}

\subsection{Introduction}

Research concerning the effect of minimum wages on employment in Indonesia has recently been undertaken by Suryahadi, et al. (2001). This study was reviewed briefly in Chapter 2. It is a major piece of work. In recognition that one of the major issues that arises 
when undertaking empirical work for a developing country is that of data quality, Suryahadi et al. (2001) have devoted considerable time to the preparation of their extensive data base. Suryahadi has kindly made available his panel data set for analysis in this paper. This presents an opportunity to learn from his remarkable and extensive analyses, and advance research on the effects of minimum wages on employment in Indonesia.

In line with Suryahadi's data, this study examines data for 26 provinces, covering the period from 1988 to 1999. A focus is on the specific groups of workers within the urban formal sector, such as females, youth workers, and less educated workers, which have been identified in many previous studies as the groups most vulnerable to changes in minimum wages. The plan of this chapter is as follows. The next section uses graphical analysis to illustrate the employment effect in the provinces with the largest urban formal employment. Section 2.3 describes the results of the statistical analysis. Finally, we end the chapter with some conclusions.

\subsection{The Employment Effect in Some Provinces}

To illustrate the relationship between the minimum wage and employment in Indonesia, we take observations for the provinces of Jawa Barat and Jawa Timur, since these provinces represent the largest proportions of urban formal workers in Indonesia $(22.2 \%$ and $16.9 \%$ of all the urban formal workers, respectively). Figures 4 and 5 below show the ratio of the nominal regional minimum wage (MW) to the nominal average wage (AW) and the employment ratio in Jawa Barat and Jawa Timur from 1988 to 1999. The minimum wage is the same for all groups, but the average wage is computed for specific groups. Therefore, the $\mathrm{MW} / \mathrm{AW}$ ratio will vary across groups. Meanwhile, the employment ratio (or share) is measured by the proportion of the specified group of workers to total workers.

Figure 4

Minimum Wage and Employment in Jawa Barat, 1988 - 1999

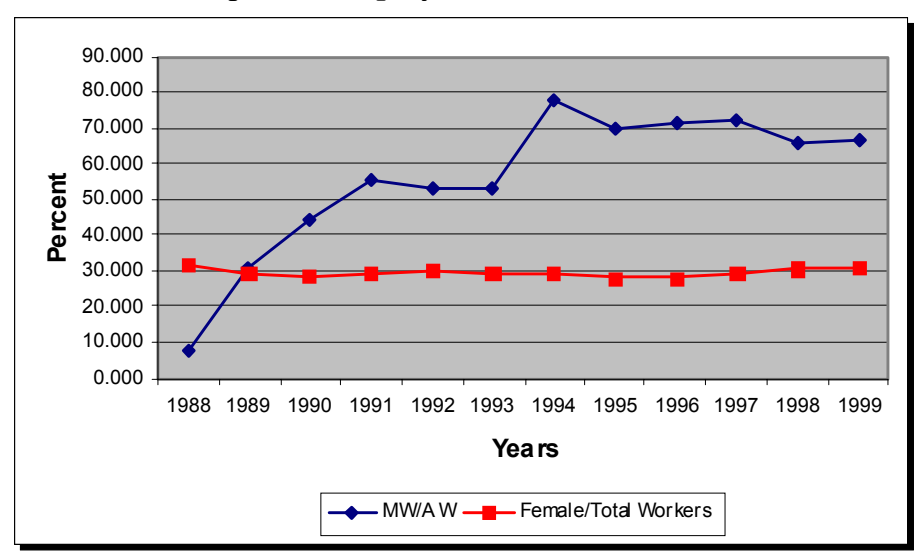



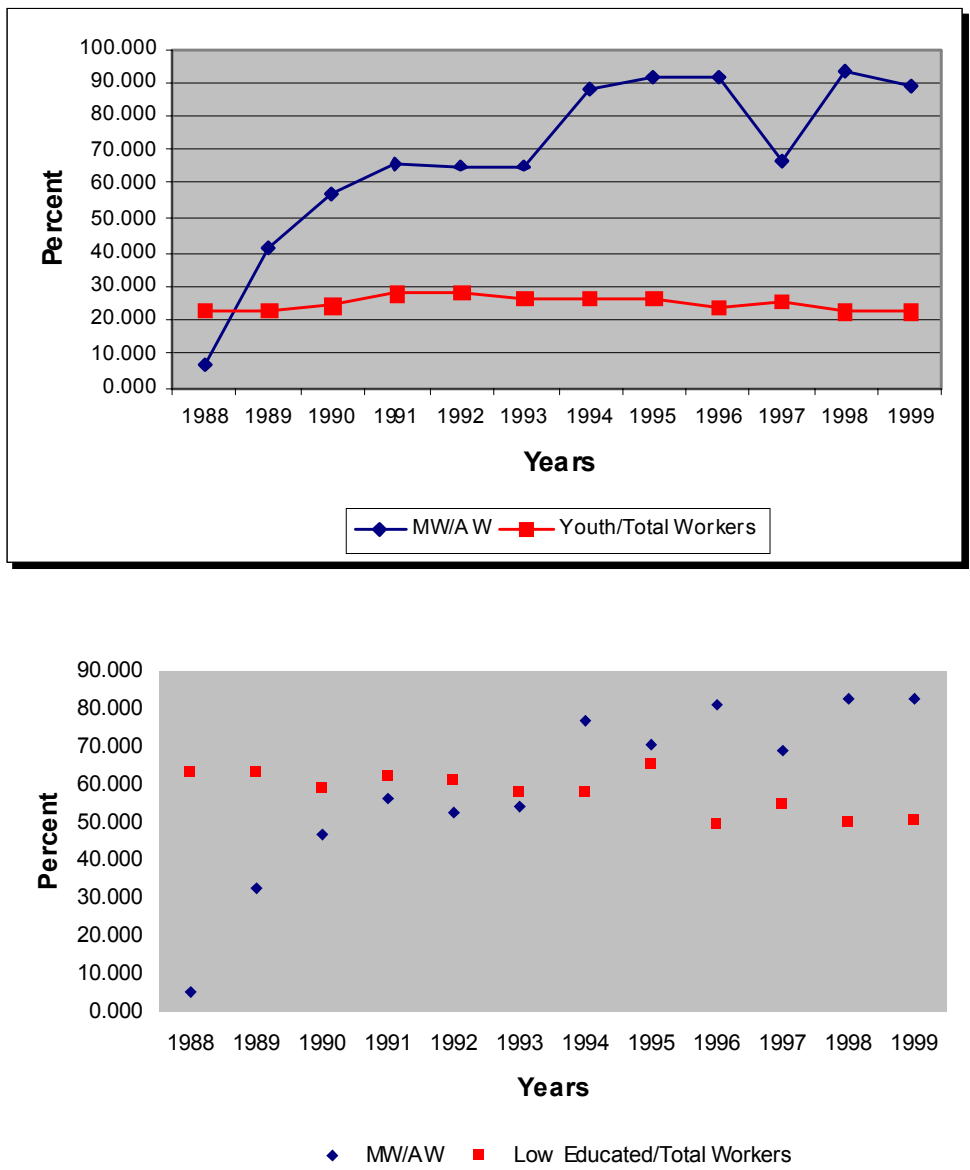

Figure 5

Minimum Wage and Employment in Jawa Timur, 1988 - 1999

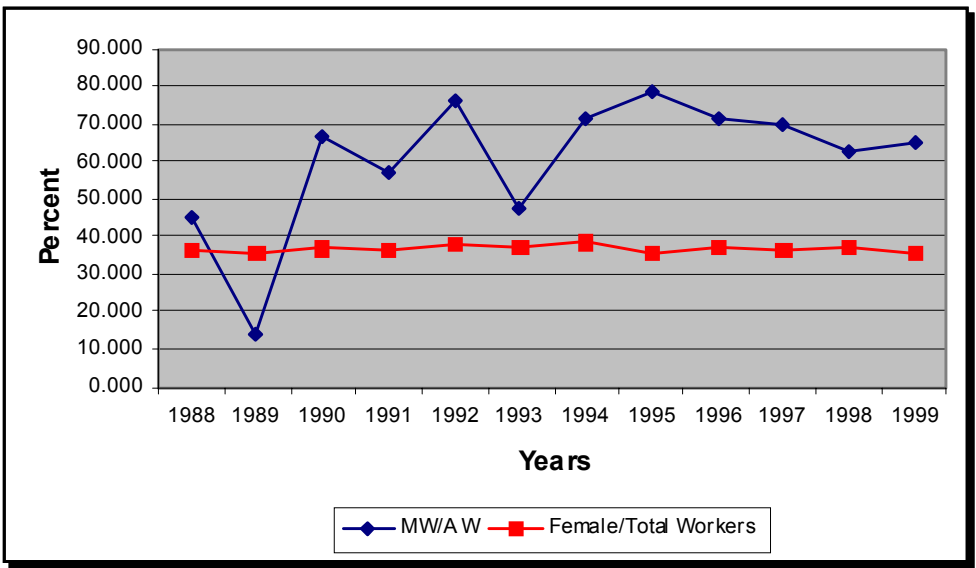



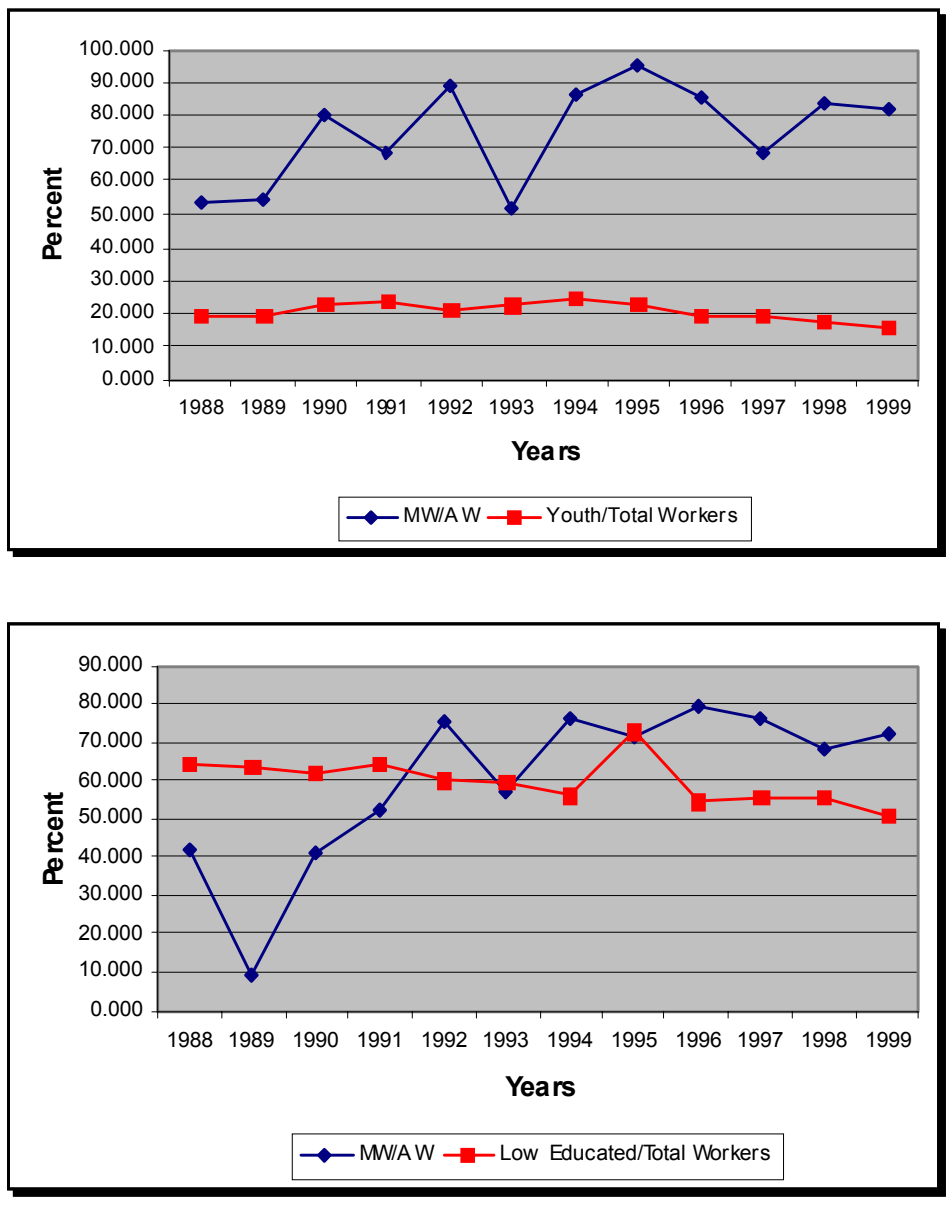

A slight negative relationship between the ratio of MW/ AW and the employment ratio in Jawa Barat is evident in the data presented for females and the youth workers group. Hence, the employment ratio decreased when MW/AW increased, and vice versa. However, the most obvious employment effect of changes in the minimum wage is shown by the low educated workers group. When the ratio of MW/ AW increased from 5.4\% in 1988 to $47.0 \%$ in 1990 , the employment ratio decreased from $63.2 \%$ to $58.7 \%$. Furthermore, when the ratio of MW/ AW fell from 76.7\% in 1994 to $70.3 \%$ in 1995, and from 81.3\% in 1996 to $68.9 \%$ in 1997, the employment ratio rose from $58.0 \%$ in 1994 to $65.4 \%$ in 1995 and from $49.3 \%$ in 1996 to $54.6 \%$ in 1997.

Similarly, in Jawa Timur, the low educated workers group is characterised by the most obvious effect of the minimum wage: increases in the MW/AW ratio have been followed by decreases in the employment ratio. For example, when the ratio of MW/ AW decreased from $75.7 \%$ in 1994 to $71.8 \%$ in 1995 , the employment ratio increased from $55.7 \%$ to $72.6 \%$. It also 
can be seen from Figure 5 that the increase in the MW/ AW ratio from $68.3 \%$ in 1998 to $72.1 \%$ in 1999 was followed by a decrease in the ratio of employment from $55.0 \%$ to $50.3 \%$.

These graphical presentations indicate some support for the conventional theory of the employment effects of minimum wages. At the same time, however, it needs to be appreciated that the changes in the minimum wages were very pronounced, particularly in the first half of the data period analysed. Perhaps far greater employment effects might therefore have been expected. It is possible, of course, that the true employment effects of the changes in minimum wages are much larger than those evident from the graphs. Other factors which are not taken into account in the bivariate displays in Figures 4 and 5 may mute these true effects. This possibility is explored in the statistical analyses that follow.

\subsection{The Statistical Analysis}

The imposition of minimum wages can be expected to have a different impact on different groups of workers. In recognition of this, Suryahadi, et al. (2001) conducted separate analyses for various groups of workers, using the log of employment for the various groups as the dependent variable. Their analysis concentrated on the urban formal sector, since this segment is most affected by minimum wage regulations. The independent variables were the minimum wage, a variable that recorded the degree of compliance with the minimum wage, a labour demand shifter and a labour supply shifter. The labour supply shifter was provided by the relevant urban population of working age, while the labour demand shifter was the real regional Gross Domestic Product (GDP). As well, reflecting the pooled time-series crosssection nature of the analysis, dummy variables were entered into the estimating equation for year (11 variables) and province ( 25 variables). The results of the estimations in the study by Suryahadi, et al. (2001) are presented in Table 10 below.

As can be seen from Table 10, Suryahadi, et al.'s (2001) results appear to be consistent with the conventional theory. There is a negative relationship between employment and the real minimum wage. The degree of compliance variable is negative and significant for the groups most sensitive to variations in parameters of a minimum wage regime (i.e., females, youth, less educated and part-time workers). Demand-side considerations, as captured by the log of real regional GDP, however, are generally insignificant. In comparison, supply side considerations are of over-whelming importance.

While this set of results appears to be quite strong, there are several issues of concern. First, the $\mathrm{R}^{2}$ values are very high. While empirical research may place a premium on high $\mathrm{R}^{2}$, values of 0.99 for pooled time-series cross-section data are quite extraordinary. The reason for the high $\mathrm{R}^{2}$ seems to be the key role played by the labour supply variable. Closer examination of this variable shows a coefficient insignificantly different (and usually 
Table 10

Results of Estimation of Employment Regression in the Study by Suryahadi, et al. (2001)

(Dependent variable: Log of employment)

\begin{tabular}{|c|c|c|c|c|c|c|c|c|c|c|c|}
\hline Regressor & Total & Male & Female & Adult & Youth & Educated & $\begin{array}{l}\text { Less } \\
\text { Educated }\end{array}$ & $\begin{array}{l}\text { White- } \\
\text { collar }\end{array}$ & $\begin{array}{l}\text { Blue- } \\
\text { collar }\end{array}$ & $\begin{array}{l}\text { Full- } \\
\text { time }\end{array}$ & $\begin{array}{l}\text { Part- } \\
\text { time }\end{array}$ \\
\hline Intercept & $\begin{array}{c}0.055 \\
(0.088)\end{array}$ & $\begin{array}{l}-0.471 \\
(0.831)\end{array}$ & $\begin{array}{c}2.895 \\
(2.604)\end{array}$ & $\begin{array}{l}-0.108 \\
(0.178)\end{array}$ & $\begin{array}{c}1.762 \\
(1.173)\end{array}$ & $\begin{array}{l}-0.262 \\
(0.445)\end{array}$ & $\begin{array}{c}0.174 \\
(0.205)\end{array}$ & $\begin{array}{l}-13.879 \\
(1.384)\end{array}$ & $\begin{array}{c}2.786 \\
(0.667)\end{array}$ & $\begin{array}{l}-0.532 \\
(0.828)\end{array}$ & $\begin{array}{c}2.037 \\
(0.852)\end{array}$ \\
\hline Log of real minimum wage & $\begin{array}{l}-0.112 \\
(3.031)\end{array}$ & $\begin{array}{l}-0.065 \\
(1.874)\end{array}$ & $\begin{array}{l}-0.307 \\
(4.642)\end{array}$ & $\begin{array}{l}-0.066 \\
(1.801)\end{array}$ & $\begin{array}{l}-0.307 \\
(3.349)\end{array}$ & $\begin{array}{l}-0.017 \\
(0.480)\end{array}$ & $\begin{array}{l}-0.196 \\
(3.787)\end{array}$ & $\begin{array}{l}1.000 \\
(2.086)\end{array}$ & $\begin{array}{l}-0.140 \\
(0.699)\end{array}$ & $\begin{array}{l}-0.086 \\
(2.248)\end{array}$ & $\begin{array}{l}-0.364 \\
(2.560)\end{array}$ \\
\hline $\begin{array}{l}\text { Log of population group } 15 \\
\text { years old and over }\end{array}$ & $\begin{array}{c}0.997 \\
(35.016)\end{array}$ & $\begin{array}{c}1.004 \\
(38.260)\end{array}$ & $\begin{array}{c}0.949 \\
(18.411)\end{array}$ & $\begin{array}{c}0.975 \\
(35.655)\end{array}$ & $\begin{array}{c}1.052 \\
(15.304)\end{array}$ & $\begin{array}{c}0.960 \\
(37.694)\end{array}$ & $\begin{array}{c}1.038 \\
(26.433)\end{array}$ & $\begin{array}{l}1.145 \\
(2.114)\end{array}$ & $\begin{array}{c}0.779 \\
(3.457)\end{array}$ & $\begin{array}{c}1.007 \\
(34.134)\end{array}$ & $\begin{array}{c}0.911 \\
(8.299)\end{array}$ \\
\hline Log of real regional GDP & $\begin{array}{c}0.014 \\
(1.275)\end{array}$ & $\begin{array}{c}0.020 \\
(1.935)\end{array}$ & $\begin{array}{c}0.013 \\
(0.652)\end{array}$ & $\begin{array}{c}0.018 \\
(1.597)\end{array}$ & $\begin{array}{l}-0.004 \\
(0.131)\end{array}$ & $\begin{array}{l}-0.001 \\
(0.065)\end{array}$ & $\begin{array}{c}0.034 \\
(2.190)\end{array}$ & $\begin{array}{l}-0.127 \\
(1.177)\end{array}$ & $\begin{array}{c}0.047 \\
(1.058)\end{array}$ & $\begin{array}{c}0.010 \\
(0.828)\end{array}$ & $\begin{array}{c}0.068 \\
(1.577)\end{array}$ \\
\hline Degree of compliance & $\begin{array}{l}-0.371 \\
(2.194)\end{array}$ & $\begin{array}{c}-0.137 \\
(0.860)\end{array}$ & $\begin{array}{l}-1.177 \\
(3.879)\end{array}$ & $\begin{array}{l}-0.165 \\
(0.984)\end{array}$ & $\begin{array}{l}-1.414 \\
(3.371)\end{array}$ & $\begin{array}{c}0.059 \\
(0.360)\end{array}$ & $\begin{array}{l}-0.838 \\
(3.537)\end{array}$ & $\begin{array}{c}0.009 \\
(0.010)\end{array}$ & $\begin{array}{l}-0.609 \\
(1.687)\end{array}$ & $\begin{array}{l}-0.217 \\
(1.236)\end{array}$ & $\begin{array}{l}-1.958 \\
(3.003)\end{array}$ \\
\hline Province dummies & Yes & Yes & Yes & Yes & Yes & Yes & Yes & Yes & Yes & Yes & Yes \\
\hline Year dummies & Yes & Yes & Yes & Yes & Yes & Yes & Yes & Yes & Yes & Yes & Yes \\
\hline Summary Statistics & Total & Male & Female & Adult & Youth & Educated & $\begin{array}{c}\text { Less } \\
\text { Educated }\end{array}$ & $\begin{array}{l}\text { White- } \\
\text { collar }\end{array}$ & $\begin{array}{l}\text { Blue- } \\
\text { collar }\end{array}$ & $\begin{array}{l}\text { Full- } \\
\text { time }\end{array}$ & $\begin{array}{l}\text { Part- } \\
\text { time }\end{array}$ \\
\hline $\mathrm{R}^{2}$ & 0.998 & 0.998 & 0.994 & 0.998 & 0.989 & 0.998 & 0.996 & 0.996 & 0.995 & 0.998 & 0.964 \\
\hline F-statistic & 2973.0 & 3198.8 & 1038.1 & 2894.3 & 606.8 & 2771.7 & 1741.1 & 102.4 & 744.8 & 2806.4 & 179.5 \\
\hline
\end{tabular}


numerically very close) to unity. This is the case even for the groups most vulnerable to the minimum wage: in such cases shifts in supply might reasonably be argued to result in unemployment or a shift to the informal sector rather than changes in employment.

Second, the demand-side variable (log of real regional GDP) is insignificant (at the 5\% level) in 10 of the 11 regression equations. Third, it is unclear how robust the set of results report in Table 10 is.

Given the above, this paper explores a number of alternative specifications of the estimating equation. In examining these alternatives, the comprehensive survey by Brown, Gilroy and Kohen (1982) serves as a guide.

The first specification issue that might be examined is the choice of dependent variable. The main alternative to the level of employment is an employment ratio. Brown, Gilroy, and Kohen (1982, p.497), for example, stated that the ratio of employment to population is used most often as the dependent variable to measure the employment effect of the minimum wage. Therefore, the regression model to be estimated specifies the log of the group-specific employment ratio as the dependent variable. ${ }^{26}$

According to Brown, Gilroy, and Kohen (1982), there are three main alternative ways of measuring the minimum wage. First, the minimum wage may be measured by the ratio of the nominal minimum wage to average hourly earnings, weighted by coverage. Second, the minimum wage may be measured by the ratio of the minimum wage to average hourly earnings, ignoring coverage. Third, the influence of the minimum wage can be represented by the real minimum wage. The two studies of the Indonesian labour market to date have used the latter two measures. Thus, Rama (2001) used the second alternative, specifically he used the ratio of the minimum wage to the average earnings of urban labourers and the ratio of the minimum wage to the average wage in manufacturing. In comparison, Suryahadi, et al. (2001) used the third alternative of the real minimum wage. To check the robustness of the results, this study uses both alternatives of the minimum wage variable employed to date in empirical studies of the Indonesian labour market. As well, while most studies surveyed by Brown, et al. (1982) used a minimum wage of the same time dimension as the dependent variable, some studies have considered a lagged value of the minimum wage. That is important where, due to the presence of contracts or other adjustment factors, changes in minimum wages affect employment outcomes with a lag. This possibility is examined by including a one-period lagged value of the minimum wage variable in the estimating equation. ${ }^{27}$

26An alternative employment ratio variable would be to use a specific group's share of total employment. This has the advantage of netting out the influence of factors (e.g. financial crisis) that might have the same effect on all groups of workers.

27 As we have only 12 years of data, more complex lag structures will not be considered. 
An aggregate demand variable, given by the log of real regional GDP, is included in the estimations to take account of the economic conditions. This type of variable is typically included in minimum wage studies, and alternatives will not be explored.

In comparison to the study which is the departure point for the analyses presented below, since the dependent variable is the ratio of employment to population, the population variable is omitted from the estimation. However, as used in the study by Suryahadi, et al. (2001), we control for the effect of variations in the degree of compliance through a measure given by the proportion of workers who earn above the minimum wage. In addition, province dummies are included in the estimations to represent the fixed effects of provincial specific characteristics which do not vary across time. Similarly, year dummy variables are included to measure specific time effects. This equation is estimated using the Ordinary Least Squares (OLS) method for all workers and various groups of workers. The results of the estimations are presented in Table 11 below.

As can be seen from Table 11, the $\mathrm{R}^{2}$ values indicate that the model can explain between 69 and 83 percent of the variations in the provincial employment data. This suggests that the high values of $R^{2}$ in the Suryahadi, et al.'s (2001) estimation, as recorded in Table 10, are due to the influence of the supply-side variable. Omitting this variable from the estimations in Table 11 has resulted in relatively lower $\mathrm{R}^{2}$ values.

It is important to note that since the population variable in Table 10 had a coefficient close to 1 , there should be minimal differences between the estimated coefficients in Tables 10 and 11. For example, the regression results for total workers in Table 11 indicate that the elasticity of total workers to the minimum wage is -0.112 . This is the same as the coefficient of the minimum wage variable in Table 10. This suggests that every 10 percent increase in real minimum wages will led to a 1.12 percent reduction in the employment of total workers. In comparison, the female workers' employment elasticity with respect to the minimum wage is -0.310 , which implies that a 10 percent increase in the real minimum wages will decrease the employment of female workers by 3.10 percent. The elasticity of youth workers with respect to the minimum wage is -0.303 , while for less educated workers it is -0.192 . These coefficients are statistically significant. However, while the coefficients of the minimum wage variables for male, adult and educated workers have a negative sign, they are insignificant.

The second alternative specification of the estimating equation, as given in Table 12, uses a specific group's share of total employment as the dependent variable. The set of independent variables used in these estimations is the same as that used in Table 11. These estimations have $\mathrm{R}^{2}$ values between 69 and 90 percent. The coefficients of the minimum wage variable for the so-called vulnerable groups are negative. Their employment elasticities are - 


\begin{tabular}{|c|c|c|c|c|c|c|c|}
\hline \multicolumn{8}{|c|}{ Results of Estimation of Employment Reg } \\
\hline Regressor & Total & Male & Female & Adult & Youth & Educated & $\begin{array}{c}\text { Less } \\
\text { Educated }\end{array}$ \\
\hline Intercept & $\begin{array}{c}0.054 \\
(0.101)\end{array}$ & $\begin{array}{l}-0.417 \\
(0.825)\end{array}$ & $\begin{array}{c}2.400 \\
(2.479)\end{array}$ & $\begin{array}{l}-0.472 \\
(0.888)\end{array}$ & $\begin{array}{c}2.863 \\
(2.138)\end{array}$ & $\begin{array}{l}-0.544 \\
(1.032)\end{array}$ & $\begin{array}{c}0.741 \\
(0.982)\end{array}$ \\
\hline Log of real minimum wage & $\begin{array}{l}-0.112 \\
(3.049)\end{array}$ & $\begin{array}{l}-0.065 \\
(1.872)\end{array}$ & $\begin{array}{l}-0.310 \\
(4.679)\end{array}$ & $\begin{array}{l}-0.067 \\
(1.854)\end{array}$ & $\begin{array}{l}-0.303 \\
(3.311)\end{array}$ & $\begin{array}{l}-0.019 \\
(0.531)\end{array}$ & $\begin{array}{l}-0.192 \\
(3.721)\end{array}$ \\
\hline Log of real regional GDP & $\begin{array}{c}0.014 \\
(1.273)\end{array}$ & $\begin{array}{c}0.020 \\
(1.949)\end{array}$ & $\begin{array}{c}0.012 \\
(0.592)\end{array}$ & $\begin{array}{c}0.017 \\
(1.553)\end{array}$ & $\begin{array}{c}-0.002 \\
(0.070)\end{array}$ & $\begin{array}{l}-0.001 \\
(0.099)\end{array}$ & $\begin{array}{c}0.036 \\
(2.276)\end{array}$ \\
\hline Degree of compliance & $\begin{array}{l}-0.373 \\
(2.234)\end{array}$ & $\begin{array}{l}-0.134 \\
(0.848)\end{array}$ & $\begin{array}{l}-1.212 \\
(4.019)\end{array}$ & $\begin{array}{l}-0.186 \\
(1.126)\end{array}$ & $\begin{array}{l}-1.381 \\
(3.313)\end{array}$ & $\begin{array}{c}0.026 \\
(0.160)\end{array}$ & $\begin{array}{l}-0.810 \\
(3.445)\end{array}$ \\
\hline $\begin{array}{l}\text { Province dummies } \\
\text { Year dummies }\end{array}$ & $\begin{array}{l}\text { Yes } \\
\text { Yes }\end{array}$ & $\begin{array}{l}\text { Yes } \\
\text { Yes }\end{array}$ & $\begin{array}{l}\text { Yes } \\
\text { Yes }\end{array}$ & $\begin{array}{l}\text { Yes } \\
\text { Yes }\end{array}$ & $\begin{array}{l}\text { Yes } \\
\text { Yes }\end{array}$ & $\begin{array}{l}\text { Yes } \\
\text { Yes }\end{array}$ & $\begin{array}{l}\text { Yes } \\
\text { Yes }\end{array}$ \\
\hline Summary Statistics & Total & Male & Female & Adult & Youth & Educated & $\begin{array}{c}\text { Less } \\
\text { Educated }\end{array}$ \\
\hline $\begin{array}{l}\mathrm{R}^{2} \\
\text { F-statistic }\end{array}$ & $\begin{array}{c}0.790 \\
26.245\end{array}$ & $\begin{array}{c}0.746 \\
20.448\end{array}$ & $\begin{array}{c}0.815 \\
30.715\end{array}$ & $\begin{array}{c}0.694 \\
15.824\end{array}$ & $\begin{array}{c}0.833 \\
34.697\end{array}$ & $\begin{array}{c}0.722 \\
18.175\end{array}$ & $\begin{array}{c}0.827 \\
33.344\end{array}$ \\
\hline
\end{tabular}


0.231 for female workers, -0.187 for youth workers, and -0.049 for less educated workers. The coefficients for female and youth workers are significant, but the coefficient for less educated workers is, surprisingly, insignificant. Meanwhile, the coefficients of the minimum wage variable for the other groups are positive. It should be noted that as these equations are share equations, positive wage coefficients are expected for the less vulnerable groups. That is, for example, if an increase in the minimum wage reduces the employment share of vulnerable groups from 0.5 to 0.25 , it must increase the employment share of other groups from 0.5 to 0.75 . The anomalous result for the less-educated workers in Table 12 suggests that the specification of the dependent variable used by Suryahadi, et al. (2001) (see Table 11) yields more robust findings.

The third alternative is presented in Table 13. The dependent and independent variables are the same as those used in Table 11. In addition, the log of the real average wage of various work force segments is included as an explanatory variable. The $\mathrm{R}^{2}$ values indicate that the model can explain between 69 and 83 percent of the variations in the provincial employment data. It seems that including the average wage variable does not change much the result of the estimations. There are minimal differences between the estimated coefficients in Table 11 and 13. The importance result from this table, however, arises from a comparison of the magnitudes of the coefficients on the minimum wage and average wage variables. Recall that many minimum wage studies use the logarithm of the ratio of minimum wages to average wages as an explanatory variable. Such a variable suggests that the coefficients on the minimum wage and average wage variables in the Table 13 specification should be equal in absolute value but opposite in sign. It is readily apparent that the coefficients do not conform to this pattern. This, together with the general insignificance of the average wage variable (and one anomalous result) suggests a preference for the real minimum wage variable used by Suryahadi, et al. (2001).

The fourth alternative uses the same dependent and independent variables as were used in Table 11. However, in these estimations, the minimum wage variable is replaced by its one period lag. The results of the estimations are presented in Table 14 . The $\mathrm{R}^{2}$ values are between 69 and 83 percent. There is a negative relationship between employment and the real minimum wage in all segments. The real minimum wage coefficients are significant for the groups most sensitive to variations in parameters of a minimum wage regime (i.e., females, youth and less educated workers). The log of real regional GDP and the degree of compliance, however, are generally insignificant. While these estimations are based on a sample that is different from that used in Table 11 (due to the need to omit the first observation for each province when the lagged wage variable is used) and hence are not strictly comparable with the Table 11 results, they appear to be considerably weaker than the results in Table 11. In other words, changes in the minimum wage would seem to impact on employment levels 
rather quickly rather than with the one-period lag as suggested by the model employed in Table14.28

The fifth and sixth alternative models weighted all the variables based on the population for the particular group. The reason for the use of weighted least squares is that the units of observation are provinces, and these range considerably in size. While the estimating equations include province dummies, it might be more appropriate to afford greater weight in the estimation to the larger provinces. Preliminary testing of the data suggested that this might lead to a strengthening of the empirical relationships uncovered. Hence, in this preliminary testing, the sample was separated into the 13 largest and the 13 smallest provinces, and separate equations estimated for these sub-samples. The results suggested that the larger provinces were characterised by a stronger negative relationship between the real minimum wage and employment. The results of the estimations are presented in Table 15 and 16 . The $\mathrm{R}^{2}$ values for both alternatives are very high, range from 98 to 99 percent. As the dependent variable has been transformed in these estimations, these $\mathrm{R}^{2}$ are not comparable with those presented earlier.

The dependent variable in Table 15 is the weighted values of the log of the ratio of the employment levels of various groups of workers to the population. The table shows that the coefficients of the minimum wage variable for total, female, adult, youth and less educated workers are negative and statistically significant. The coefficients of the degree of compliance variable indicate that higher compliance tends to strengthen the negative impact of minimum wages on these groups of workers. All of the coefficients of real regional GDP variable, however, are insignificant.

Finally, the sixth alternative use the weighted of log of a specific group's share of total employment as dependent variable. As can be seen from Table 16, the coefficients of the minimum wage variable for female, youth and less educated workers are negative. Their employment elasticities with respect to minimum wages are -0.199 for female, -0.284 for youth, and -0.118 for less educated workers. Similarly, the coefficients of the degree of compliance variable for these groups are negative and statistically significant.

Apart from the results for male and youth groups of workers, the diagnostic tests suggest that the fifth and sixth alternatives are statistically adequate regarding functional form and normality. However, the tests indicate the problem of heteroscedasticity in both

28 To test this issue, the minimum wage and its one-period lagged value were both included in an alternative model. These results showed that the minimum wage variable, compared to its one-period lag, has a stronger negative relationship with the employment. The estimations showed that the coefficients of minimum wage variable were significant for all, male, female, youth and less educated workers. In comparison, the coefficients of its oneperiod lagged were only significant for female workers. 
alternatives. The origins of this problem could be taken into account for further research. In this study, heteroscedasticity-consistent ' $t$ ' statistics are used.

The results of all alternative specifications of the estimating equation have shown that minimum wages have a negative effect on the groups most sensitive to variations in parameters of a minimum wage regime (i.e., females, youth and less educated workers). The coefficients of minimum wage variable for the female and youth groups of workers are statistically significant in all alternatives. Apart from alternative 2, which has a negative, but insignificant, relationship the low educated workers' elasticities with respect to minimum wages are statistically significant. Similarly, the coefficients of the degree of compliance variable for these groups are negative and, in general, statistically significant. The coefficients of this variable in the estimations for females are statistically significant in all alternatives. In alternative 4 , the coefficients for youth and low educated workers are negative but insignificant.

\subsection{Conclusion}

Using data for 26 provinces, covering the period from 1988 to 1999 , this study examines the impact of minimum wages on the specific groups of workers within the urban formal sector.

Bivariate analyses presented for some provinces that represent the largest shares of urban formal sector workers indicate some support for the conventional theory of negative employment effects of minimum wages.

The statistical analysis confirms the results of the graphical analysis. It is shown that minimum wages have a negative effect on the groups most sensitive to variations in parameters of a minimum wage regime (i.e., females, youth and less educated workers). Moreover, the analyses show that the specification adopted by Suryahadi, et al. (2001) in their comprehensive report is among the best of the available models. The only change that might be recommended is the use of weighted least squares to take account of the considerable differences in the population sizes of the provinces. 


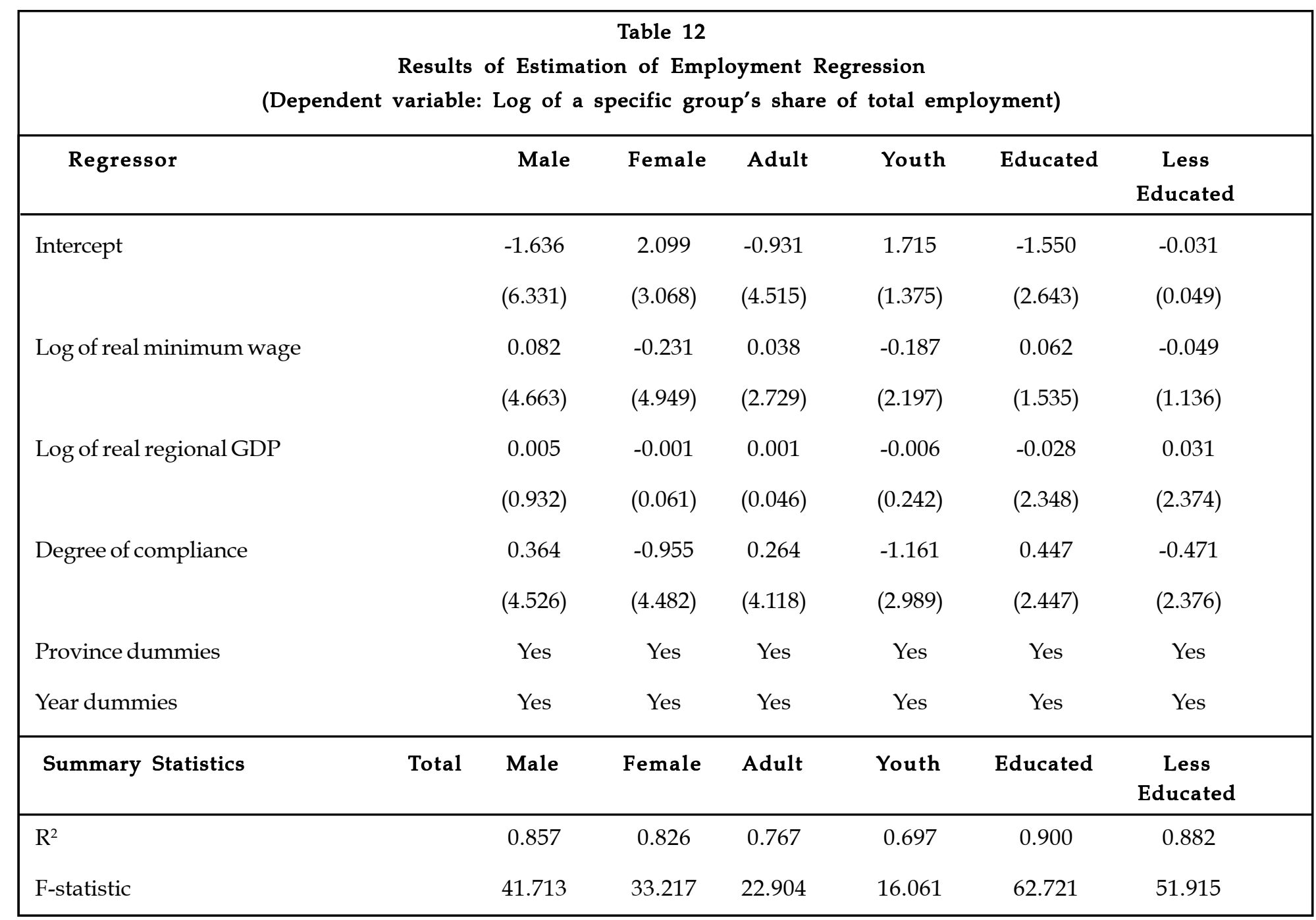




\begin{tabular}{|c|c|c|c|c|c|c|c|}
\hline (Dependent varia & $\begin{array}{l}\text { Results } \\
g \text { of the }\end{array}$ & $\begin{array}{l}\text { ff Estim } \\
\text { ratio of }\end{array}$ & $\begin{array}{l}\text { Table } 13 \\
n \text { of Emp } \\
\text { loyment }\end{array}$ & $\begin{array}{l}\text { yyment } R \\
\text { specific }\end{array}$ & $\begin{array}{l}\text { ession } \\
\text { ups of }\end{array}$ & kers to pop & lation) \\
\hline Regressor & Total & Male & Female & Adult & Youth & Educated & $\begin{array}{c}\text { Less } \\
\text { Educated }\end{array}$ \\
\hline Intercept & $\begin{array}{c}0.176 \\
(0.314)\end{array}$ & $\begin{array}{l}-0.783 \\
(1.446)\end{array}$ & $\begin{array}{c}2.386 \\
(2.426)\end{array}$ & $\begin{array}{l}-0.911 \\
(1.593)\end{array}$ & $\begin{array}{l}3.156 \\
(2.352)\end{array}$ & $\begin{array}{l}-0.685 \\
(1.241)\end{array}$ & $\begin{array}{c}1.483 \\
(1.975)\end{array}$ \\
\hline Log of real minimum wage & $\begin{array}{l}-0.111 \\
(3.011)\end{array}$ & $\begin{array}{l}-0067 \\
(1.950)\end{array}$ & $\begin{array}{l}-0.310 \\
(4.667)\end{array}$ & $\begin{array}{l}-0.070 \\
(1.929)\end{array}$ & $\begin{array}{l}-0.289 \\
(3.167)\end{array}$ & $\begin{array}{l}-0.022 \\
(0.610)\end{array}$ & $\begin{array}{l}-0.185 \\
(3.695)\end{array}$ \\
\hline Log of real average wage & $\begin{array}{l}-0.012 \\
(0.774)\end{array}$ & $\begin{array}{l}0.036 \\
(1.832)\end{array}$ & $\begin{array}{c}0.002 \\
(0.082)\end{array}$ & $\begin{array}{c}0.043 \\
(2.014)\end{array}$ & $\begin{array}{l}-0.040 \\
(1.867)\end{array}$ & $\begin{array}{c}0.016 \\
(0.871)\end{array}$ & $\begin{array}{l}-0.075 \\
(4.369)\end{array}$ \\
\hline Log of real regional GDP & $\begin{array}{l}0.014 \\
(1.281)\end{array}$ & $\begin{array}{l}0.019 \\
(1.837)\end{array}$ & $\begin{array}{c}0.012 \\
(0.594)\end{array}$ & $\begin{array}{l}0.016 \\
(1.452)\end{array}$ & $\begin{array}{l}-0.003 \\
(0.121)\end{array}$ & $\begin{array}{l}-0.002 \\
(0.154)\end{array}$ & $\begin{array}{l}0.035 \\
(2.301)\end{array}$ \\
\hline Degree of compliance & $\begin{array}{l}-0.358 \\
(2.129)\end{array}$ & $\begin{array}{l}-0.162 \\
(1.030)\end{array}$ & $\begin{array}{l}-1.215 \\
(3.978)\end{array}$ & $\begin{array}{l}-0.230 \\
(1.387)\end{array}$ & $\begin{array}{l}-1.305 \\
(3.128)\end{array}$ & $\begin{array}{c}0.010 \\
(0.060)\end{array}$ & $\begin{array}{l}-0.696 \\
(3.038)\end{array}$ \\
\hline Province dummies & Yes & Yes & Yes & Yes & Yes & Yes & Yes \\
\hline Year dummies & Yes & Yes & Yes & Yes & Yes & Yes & Yes \\
\hline Summary Statistics & Total & Male & Female & Adult & Youth & Educated & $\begin{array}{c}\text { Less } \\
\text { Educated }\end{array}$ \\
\hline $\mathrm{R}^{2}$ & 0.791 & 0.749 & 0.815 & 0.699 & 0.835 & 0.723 & 0.838 \\
\hline F-statistic & 25.566 & 20.193 & 29.838 & 15.703 & 34.226 & 17.724 & 35.149 \\
\hline
\end{tabular}




\begin{tabular}{|c|c|c|c|c|c|c|c|}
\hline \multicolumn{8}{|c|}{$\begin{array}{l}\text { Table } 14 \\
\text { Results of Estimation of Employment Regression }\end{array}$} \\
\hline Regressor & Total & Male & Female & Adult & Youth & Educated & $\begin{array}{c}\text { Less } \\
\text { Educated }\end{array}$ \\
\hline \multirow[t]{2}{*}{ Intercept } & -0.687 & -0.945 & 0.611 & -0.890 & 0.894 & -0.637 & -0.336 \\
\hline & $(1.654)$ & $(2.493)$ & $(0.803)$ & $(2.167)$ & $(0.865)$ & $(1.558)$ & $(0.583)$ \\
\hline \multirow[t]{2}{*}{ Log of real minimum wage ${ }^{*}$} & -0.058 & -0.027 & -0.182 & -0.033 & -0.208 & -0.010 & -0.123 \\
\hline & $(1.949)$ & $(0.996)$ & $(3.342)$ & $(1.134)$ & $(2.807)$ & $(0.330)$ & $(2.995)$ \\
\hline \multirow[t]{2}{*}{ Log of real regional GDP } & 0.011 & 0.021 & -0.001 & 0.013 & 0.010 & -0.001 & 0.028 \\
\hline & $(0.969)$ & $(2.026)$ & $(0.022)$ & $(1.198)$ & $(0.378)$ & $(0.113)$ & $(1.814)$ \\
\hline \multirow[t]{2}{*}{ Degree of compliance } & -0.137 & 0.001 & -0.527 & -0.059 & -0.635 & -0.003 & -0.305 \\
\hline & $(0.984)$ & $(0.002)$ & $(2.072)$ & $(0.432)$ & $(1.838)$ & $(0.024)$ & $(1.584)$ \\
\hline Province dummies & Yes & Yes & Yes & Yes & Yes & Yes & Yes \\
\hline Year dummies & Yes & Yes & Yes & Yes & Yes & Yes & Yes \\
\hline Summary Statistics & Total & Male & Female & Adult & Youth & Educated & $\begin{array}{c}\text { Less } \\
\text { Educated }\end{array}$ \\
\hline $\mathrm{R}^{2}$ & 0.784 & 0.754 & 0.804 & 0.694 & 0.834 & 0.734 & 0.837 \\
\hline F-statistic & 23.617 & 19.966 & 26.631 & 14.775 & 32.685 & 17.896 & 33.395 \\
\hline
\end{tabular}

*Lagged by one period. 


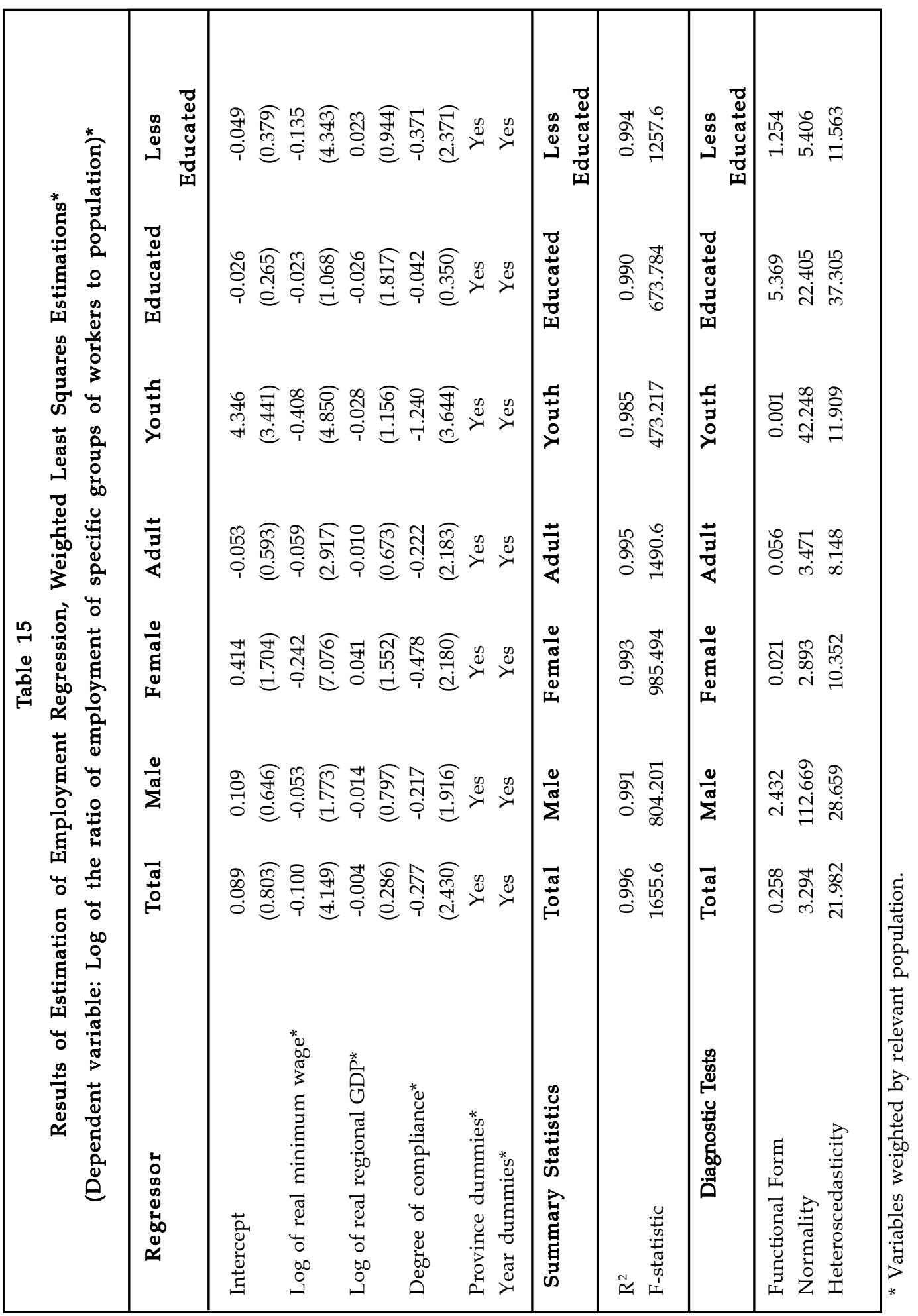




\begin{tabular}{|c|c|c|c|c|c|c|}
\hline \multicolumn{7}{|c|}{$\begin{array}{c}\text { Table } 16 \\
\text { Results of Estimation of Employment Regression, Weighted Least Squares Estimations* } \\
\text { (Dependent variable: Log of a specific group's share of total employment)* }\end{array}$} \\
\hline Regressor & Male & Female & Adult & Youth & Educated & $\begin{array}{c}\text { Less } \\
\text { Educated }\end{array}$ \\
\hline Intercept & $\begin{array}{c}0.119 \\
(1.075)\end{array}$ & $\begin{array}{c}0.393 \\
(1.852)\end{array}$ & $\begin{array}{c}0.233 \\
(5.213)\end{array}$ & $\begin{array}{c}2.763 \\
(2.798)\end{array}$ & $\begin{array}{c}0.923 \\
(8.315)\end{array}$ & $\begin{array}{c}0.824 \\
(6.263)\end{array}$ \\
\hline Log of real minimum wage* & $\begin{array}{c}0.013 \\
(0.667)\end{array}$ & $\begin{array}{l}-0.199 \\
(6.404)\end{array}$ & $\begin{array}{l}-0.016 \\
(1.500)\end{array}$ & $\begin{array}{l}-0.284 \\
(4.348)\end{array}$ & $\begin{array}{l}-0.036 \\
(1.110)\end{array}$ & $\begin{array}{l}-0.118 \\
(6.081)\end{array}$ \\
\hline Log of real regional GDP* & $\begin{array}{l}-0.028 \\
(2.049)\end{array}$ & $\begin{array}{c}0.042 \\
(2.021)\end{array}$ & $\begin{array}{l}-0.015 \\
(1.771)\end{array}$ & $\begin{array}{l}-0.015 \\
(0.750)\end{array}$ & $\begin{array}{l}-0.056 \\
(2.205)\end{array}$ & $\begin{array}{c}0.007 \\
(0.471)\end{array}$ \\
\hline Degree of compliance* & $\begin{array}{l}-0.125 \\
(1.513)\end{array}$ & $\begin{array}{l}-0.376 \\
(2.309)\end{array}$ & $\begin{array}{l}-0.141 \\
(2.323)\end{array}$ & $\begin{array}{l}-0.991 \\
(3.514)\end{array}$ & $\begin{array}{l}-0.359 \\
(2.352)\end{array}$ & $\begin{array}{l}-0.553 \\
(4.012)\end{array}$ \\
\hline Province dummies* & Yes & Yes & Yes & Yes & Yes & Yes \\
\hline Year dummies* & Yes & Yes & Yes & Yes & Yes & Yes \\
\hline Summary Statistics & Male & Female & Adult & Youth & Educated & $\begin{array}{c}\text { Less } \\
\text { Educated }\end{array}$ \\
\hline $\begin{array}{l}\mathrm{R}^{2} \\
\text { F-statistic }\end{array}$ & $\begin{array}{c}0.990 \\
668.117\end{array}$ & $\begin{array}{c}0.992 \\
894.619\end{array}$ & $\begin{array}{c}0.988 \\
556.872\end{array}$ & $\begin{array}{c}0.989 \\
647.061\end{array}$ & $\begin{array}{c}0.994 \\
1113.2\end{array}$ & $\begin{array}{c}0.984 \\
421.152\end{array}$ \\
\hline Diagnostic Tests & Male & Female & Adult & Youth & Educated & $\begin{array}{c}\text { Less } \\
\text { Educated }\end{array}$ \\
\hline Functional Form & 33.127 & 3.571 & 1.568 & 0.001 & 4.141 & 1.233 \\
\hline Normality & 63.097 & 19.409 & 9.118 & 113.831 & 32.780 & 23.622 \\
\hline Heteroscedasticity & 25.717 & 18.883 & 44.513 & 14.355 & 48.538 & 47.753 \\
\hline
\end{tabular}

* Variables weighted by relevant population. 


\section{CONCLUSION}

The theoretical effects of a minimum wage seem to be ambiguous. The competitive labour market model suggests that the introduction of a minimum wage that raises the wages of some workers would automatically reduce the employment prospects of that particular category of workers. The monopsony and efficiency wage models, however, suggest that the link between wages and employment is not automatically negative, and might be positive. These ambiguous theoretical conclusions are also reflected in the available empirical evidence.

With respect to the debate on the minimum wage, this study examines the impact of increases in minimum wages on specific groups of workers within the urban formal sector in Indonesia. The results from previous studies of the Indonesian labour market by Rama (2001) and Suryahadi, et al. (2001) serve as a benchmark.

Bivariate analyses for some provinces that represent the largest shares of urban formal workers have shown that there is a slight negative relationship between the ratio of minimum wage to average wage and the employment ratio. The results of statistical analysis strengthen the results of the graphical analysis. Using the comprehensive survey by Brown, Gilroy and Kohen (1982) as a guide, a number of alternative specifications of the estimating equation are explored. The results of all alternatives have shown that minimum wages have a negative effect on employment for the groups most sensitive to variations in parameters of a minimum wage regime (i.e., females, youth and less educated workers).

As an implication, increases in the minimum wages that are higher than productivity gains may reduce Indonesia's export competitiveness and create a barrier to new investments. Therefore, the government should keep the minimum wages in line with productivity that is determined at the firm level. This might be achieved through negotiation between employers and workers' union. 


\section{REFERENCES}

Abdullah, F. and Etty, T., 1995, “Would be and Make Believe in Crisis", in Harris, D.R. (ed.), Prisoners of Progress: A Review of The Current Indonesian Labour Situation, FNV, INDOC, INFIC, Netherlands, pp. 33-46.

Bank Indonesia (Central Bank of Republic of Indonesia), 2002, "Inflation Report”, [Homepage of Bank Indonesia], [Online], Available: http://www.bi.go.id/bank_indonesia_english/ monetary/inflation/, [2002, 10 February].

Berman, R.B., 1996, "The Crippling Flaws in the New Jersey Fast Food Study", [Homepage of Employment Policies Institute], [Online], Available: http://www.epionline.org/ study_epi_njfast_04-1996.pdf, [2001, 19 December].

Beth, M.J., 2001 (a), “Asia's New Leaders: Indonesia Labour Leader Forges Ahead”, Far Eastern Economic Review (FEER), 8 March 2001.

2001 (b) , “Lost Labour, Lost Reform”, Far Eastern Economic Review (FEER), 15 March 2001.

Biro Pusat Statistik Indonesia (Indonesian Central Bureau of Statistics), 1997(a), Labourer/ Employees Situation in Indonesia August 1997, Cat. No. 3404, Jakarta 1997(b),

Labour Force Situation in Indonesia 1997, Cat. No. 3402, BPS, Jakarta 1997(c), Statistic

Wages 1997, Cat. No. 3407, BPS, Jakarta 1998(a), Labourer/

Employees Situation in Indonesia August 1998, Cat. No. 3404, Jakarta 1998(b),

Labour Force Situation in Indonesia 1998, Cat. No. 3402, BPS, Jakarta 1998(c), Statistic

Wages 1998, Cat. No. 3407, BPS, Jakarta 1999(a), Labourer/

Employees Situation in Indonesia August 1999, Cat. No. 3404, Jakarta 
1999(b),

Labour Force Situation in Indonesia 1999, Cat. No. 3402, BPS, Jakarta

1999(c), Statistic

Wages 1999, Cat. No. 3407, BPS, Jakarta

2000(a), Labourer/

Employees Situation in Indonesia August 2000, Cat. No. 3404, Jakarta

2000(b),

Labour Force Situation in Indonesia 2000, Cat. No. 3402, BPS, Jakarta

2000(c), Statistic

Wages 2000, Cat. No. 3407, BPS, Jakarta

2002, "Employment

Statistics", [Homepage of Indonesian Central Bureau of Statistics], [Online], Available: http://www.bps.go.id/statbysector/employ/, [2002, 21 February].

Booth, A., 1999, "The Social Impact of The Asian Crisis: What Do We Know Two Years On?", in Asia Pacific Economic Literature, v.13(2), pp.16-29.

Brown, C., Gilroy, C., and Kohen, A., 1982, “The Effect of the Minimum Wage on Employment and Unemployment", in Journal of Economic Literature, v. 20, June, pp. 487-528.

Cameron, L., 1999, "Survey of Recent Economic Development", in Bulletin of Indonesian Economic Studies, v. 35(1), pp.3-40.

Card, D. and Krueger, A., 1994, "Minimum Wages and Employment: A Case Study of the Fast-Food Industry in New Jersey and Pennsylvania." in American Economic Review, v. 84, pp. 772-793.

1995, Myth and Measurement: The New Economics of the Minimum Wage, Princeton University Press, Princeton, New Jersey.

Deere, D., Murphy, K.M., Welch, F., 1995, “Employment and the 1990-1991 Minimum-Wage Hike (in Reexamining Methods of Estimating Minimum-Wage Effects)", in American Economic Review, v. 85(2), pp. 232-237.

Fleisher, B.M. and Kniesner, T.J., 1984, Labor Economics: Theory, Evidence, and Policy, PrenticeHall, New Jersey.

Ford, M., 1999, "Testing the Limits of Corporatism: Industrial Relations in Suharto's Indonesia," in Journal of Industrial Relations , v. 41(3), pp. 372-392. 
Gall, G., 1998, "The Development of the Indonesian Labour Movement", in The International Journal of Human Resource Management, v. 9(2), pp.359-376.

Garcia, G.J. and Soelistianingsih, L., 1998, “Why Do Differences in Provincial Incomes Persist in Indonesia?", in Bulletin of Indonesian Economic Studies, v.34(1), pp. 95-120.

Ghellab, Y., 1998, “Minimum Wages and Youth Unemployment", in Employment and Training Papers 26, International Labour Office, Employment and Training Department.

Hadiz, V., 2000, "Globalisation, Labour and The State: The Case of Indonesia", in Asia Pacific Business Review, v. 6(2\&3), pp. 239-259.

Hess, M., 1990, “Industrial Relations and Developing Economies”, in Discussion Paper no. 18 Department of Industrial Relations, University of Western Australia, Nedlands, WA.

1997, “Understanding Indonesian Industrial Relations”, in The Journal of Industrial Relations, v.39(1), pp.33-51.

Hill, H., 1996, The Indonesian Economy Since 1966: Southeast Asia's Emerging Giant, Cambridge University Press, Melbourne.

Inkiriwang, R., 2001, "Menyongsong UMR 2002 Sulut" (Welcoming the 2002 Regional Minimum Wages in North Sulawesi), [Homepage of Menado Post], [Online], Available: http://www.mdopost.net/november2001/12-opini/21/01.html, [2001, 30 November].

International Labour Organisation (ILO), 2002, "The Labour Statistics Database", [Homepage of Laborsta], [Online], Available: http:/ / laborsta.ilo.org, [2002, 22 February].

Kearl, J.R., Pope, C.L., Whitting, G.C. and Wimmer, Larry T., 1979, “What Economists Think: A Confusion of Economists?" in American Economic Review, v. 69, pp. 28-37.

KOMPAS, 12 April 2000, "Ribuan Guru Unjuk Rasa di Istana Negara", (Thousands of Teachers Went on Strike to State Palace),[Homepage of KOMPAS], [Online], Available: http://www.kompas.com/berita\%2Dterbaru/0004/12/headline/09.htm,

[20 December 2001].

Lambert, R., 1993, “Authoritarian State Unionism in New Order Indonesia”, in Asia Research Centre, Working Paper no. 25.

Mankiw, G., 1997, Macroeconomics, Worth Publishers, New York.

Manning, C., 1993, “Structural Change and Industrial Relations During The Soeharto Period: An Approaching Crisis?", in Bulletin of Indonesian Economic Studies, v. 29(2), pp. 59-95. 
, 1994, "What has Happened to Wages in the New Order?", in Bulletin of Indonesian Economic Studies, 30(3), pp. 73-114. 1998a, "Indonesian Labour in Transition: An East Asian Success Story", Cambridge University Press, U.K.

1998b, "The Employment Crisis", [Homepage of Inside Indonesia], [Online], Available: http:/ / wwwinsideindonesia.org/edit55/mang.htm., [2001,30 November].

2000, “Labour Market Adjustment to Indonesia's Economic Crisis: Context, Trends and Implications", in Bulletin of Indonesian Economic Studies, v.36(1), pp. 105-136.

Miller, P.J., 2002, “The New Economics of a Minimum Wage Hike, Federal Reserve Bank of Minneapolis", [Homepage of Federal Reserve Bank of Minneapolis], [Online], Available: http://minneapolisfed.org/pubs/fedgaz/fg/EDI9510A.html, [2002, January 5].

Miller, P.W., 1983, “The Role of Labour Costs on the Youth Labour Market: An Overview of the Evidence", in Discussion Paper no.65, Centre for Economic Research, Australian National University, Canberra.

Miller, P.W. and Mulvey, C., 1989, "Union Density and The Union/Non-Union Wage Differential in Australia", in Discussion Paper no. 17, Department of Industrial Relations, University of Western Australia, Perth. and Neo, L.M., 1997, "Unions and Wages: A Further Analysis", in Discussion Paper 97/1, Centre for Labour Market Research, Curtin University of Technology, Perth.

Mincer, J., 1976, “Unemployment Effects of Minimum Wages”, in Journal of Political Economy, v. 84, August, pp. 87-104.

Neumark, D. and Wascher, W., 1995, “The Effect of New Jersey's Minimum Wage Increase on Fast-Food Employment: A Re-Evaluation Using Payroll Records", in NBER Working Paper No. 5224, National Bureau of Economic Research, Cambridge, M.A.

Nusantara, A.H.G., 1995, “Law and The Right to Organise”, in Harris, D.R. (ed), Prisoners of Progress: A Review of The Current Indonesian Labour Situation, FNV, INDOC, INFIC, Netherlands, pp. 23-32.

Packard, T.G., 2001, "Is There A Positive Incentive Effect from Privatizing Social Security?", [Online], Available:

http://www.pensions-policy.org/papers/oxford/Packard_panel_PRWP.doc [2002, 9 January]. 
Rama, M., 2001, “The Consequences of Doubling the Minimum Wage: The Case of Indonesia", in Industrial and Labor Relations Review, v. 54(4), pp. 864-881.

Romer, D., 1996, Advanced Macroeconomics, The McGraw-Hill Companies, New York.

Sidik, H., and Iskandarsyah, T., 1993, "Manajemen Sumber Daya Manusia” (Human Resource Management), Bina Ekonomi Universitas Katholik Parahyangan, Bandung, pp. 15-20.

Stigler, G.J., 1946, “The Economics of Minimum Wage Legislation”, in American Economic Review, v. 36, pp. 358-365.

Storey, I.J., 2000, “Indonesia's China Policy in The New Order and Beyond: Problems and Prospects", [Homepage of KOMPAS], [Online], Available: http:/ / www.kompas.com/ fotorene/arsip/ Indonesia \% 27s\% 20china\% 20policy\% 20in \%20 \% the 20new \%20 \% order $\% 20$ and $\% 20$ beyond $\% 20$ probelms $\% 20$ and $\% 20$ prospects.doc , [2001, 5 November].

Surbakti, S., Pratoprijoko, R.L., and Darmesto, S., 2001, “Indonesia's 2000 Population Census: A Recent Statistics Activity", [Homepage of Economic And Social Commision For Asia And The Pacific], [Online], Available: http://www.unescap.org/stat/cos12/ indonesia.pdf, [2001, 20 December].

Suryahadi, A., Widyanti, W., Perwira, D., Rahayu, S.K., Sulaksono, B., Nabiu, M., Budiyati, S., Hastuti, Akhmadi, Munawar, W., Waworuntu, O., Meiyani, D., Anwar, C., Hendratno, S., 2001, "Wage and Employment Effects of Minimum Wage Policy in the Indonesian Urban Labour Market", [Homepage of The SMERU Research Institute], [Online], Available: http://www.smeru.or.id/report/ research/minimumwage/minimum wage.htm, [2002, 4 April].

Suwarno, S. and Elliot, J., 2000, "Changing Approaches to Employment Relations in Indonesia”, in Bamber, G., Park, F., Lee, C., Ross, P., Broadbent, K., (eds), Employment Relations in the Asia Pacific: Changing Approachs, Allen and Unwin, St Leonards, NSW.

Thamrin, J., 1995, “Development Policy", in Harris D.R. (ed.), Prisoners in Progress: A Review of the Current Indonesian Labour Situation, FNV, INDOC, INFIC, Netherland, pp.1-21.

“Upah Minimum Sebuah Kajian Tentang Dampaknya Terhadap Penciptaan Lapangan Kerja di Masa Krisis" (Minimum Wage, An Analysis of the Impact of Job Creation during Crisis Era), [Homepage of Directorate of Employment of National Development Planning], [Online], Available: http://www.bappenas.go.id/bap_ind.html, [2001, 5 December]. 